\title{
Synthesis of National Wind Energy Assessments
}

by

Dennis L. Elliott

July 1977

Prepared for the Energy Research and Development Administration under Contract EY-76-C-06-1830 


\title{
NOTICE
}

This report was prepared as an account of work sponsored by the United States Government. Neither the United States nor the Energy Research and Development Administration, nor any of their employees, nor any of their contractors, subcontractors, or their employees, makes any warranty, express or implied, or assumes any legal liability or responsibility for the accuracy, completeness or usefulness of any information, apparatus, product or process disclosed, or represents that its use would not infringe privately owned rights.

The views, opinions and conclusions contained in this report are those of the contractor and do not necessarily represent those of the United States Government or the United States Energy Research and Development Administration.

PACIFIC NORTHWEST LABORATORY

operated by

BATTELLE

for the

ENERGY RESEARCH AND DEVELOPMENT ADMINISTRATION

Under Contract EY-76-C-06-1830

\author{
Printed in the United States of America \\ Available from \\ National Technical Information Service \\ U.S. Department of Commerce \\ 5285 Porn Royal Road \\ Springfield, Virginia 22751
}

Price: Printed Copy \$___; Microfiche $\$ 3.00$

$\begin{array}{cc}\text {-Pages } & \text { Selling Price } \\ 001-025 & \$ 4.50 \\ 026-050 & \$ 5.00 \\ 057-075 & \$ 5.50 \\ 076-100 & \$ 6.00 \\ 101-125 & \$ 6.50 \\ 126-150 & \$ 7.00 \\ 15 i-175 & \$ 7.75 \\ 176-200 & \$ 8.50 \\ 201-225 & \$ 8.75 \\ 226-250 & \$ 9.00 \\ 251-275 & \$ 10.00 \\ 276-300 & \$ 30.25\end{array}$


by

Dennis L. Elliott

Ju 7 y 1977

Battelle,

Pacific Northwest Laboratories

Richland, WA 99352 


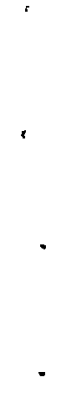




\section{SUMMARY}

The objective of this study is to perform a synthesis of existing national wind energy assessments to develop an improved consistent assessment of the geographical distribution of the available wind power over the United States. Previous national wind energy assessments have been reviewed with respect to techniques, assumptions, data sets/summaries, and interpolation schemes used. The overall representativeness of the resource maps produced has been evaluated. Discrepancies exist among previous assessments with regard to geographical variations and the estimated values of wind power.

Information from the existing national wind energy assessments and various other sources has been selectively used to form a synthesized national assessment. As part of the synthesis, additional research was performed to further improve the national assessment. This included a more detailed examination of some of the inherent problems with respect to the representativeness and reliability of the surface and rawinsonde wind data, techniques employed in the vertical extrapolation of wind power, in the estimation of wind power over mountainous and offshore areas and areas of sparse data, and in the analysis and interpolation of the values.

The refined analysis of the mean annual wind power at $50 \mathrm{~m}$ above exposed areas over the contiguous United States is shown in Figure 1. Exposed areas refer to locations which are unobstructed to the wind, such as hilltop locations over regions of gently rolling and hilly terrain, and capes and open shoreline sites along coastal regions. The estimates are considered to be lower limits for exposed sites. A few isolated areas may have $50-100 \%$ greater wind power than the analysis shows. Thus, the estimates must not be construed as representative of all sites within an area. Specifically, the estimates are not representative where topographic features block or channel airflow.

In mountainous regions, the estimates are the lower 1 imits expected for typical, well-exposed sites along mountain summits, ridges, and gaps. These estimates are primarily based on the climatology of the winds aloft. However, the relationship between mountain summit wind power and free air wind power at summit height is highly variable. Over some isolated mountains and ridges, the wind speeds are enhanced considerably, and the wind power may be a factor 


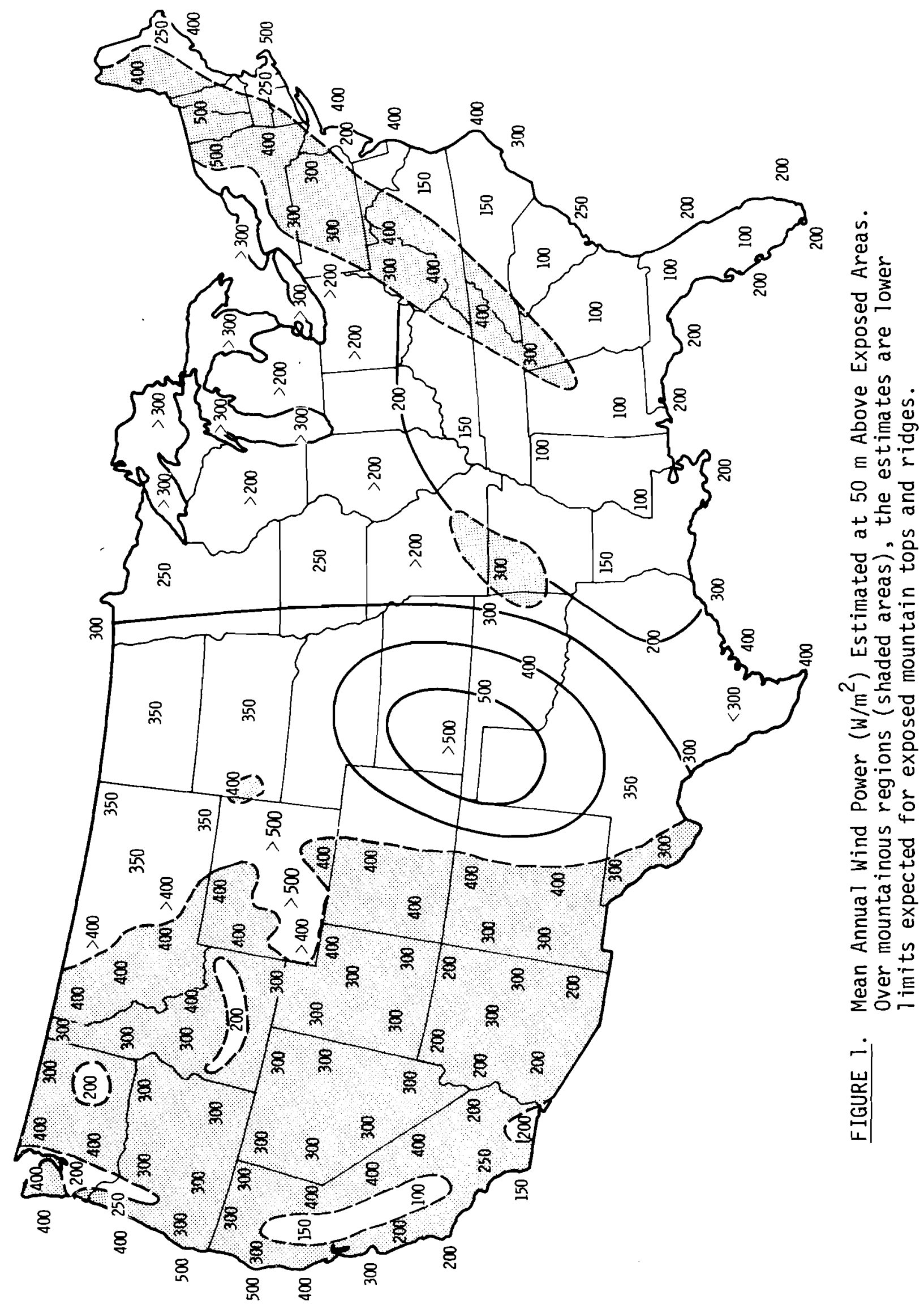


of 2 or 3 greater than the values indicated in the analyses. The slope and orientation of a ridge to the prevailing winds greatly effect the wind power. Thus, relatively low isolated ridges, gaps, and saddles, may have greater wind power than higher mountain summits. All mountainous regions, with the exception of some areas in the Southwest, are estimated to have considerable wind power potential (at least $300 \mathrm{w} / \mathrm{m}^{2}$ ). However, even the Southwest may have some well exposed sites (where the winds are enhanced) with high wind power potential.

In nonmountainous regions, the mean annual wind power is high $\left(>400 \mathrm{~W} / \mathrm{m}^{2}\right)$ over the central and southern Great Plains; offshore and exposed coastal sites in the Northeast and Northwest; and in parts of Wyoming, Montana, and the south Texas coast. High wind power $\left(>400 \mathrm{~W} / \mathrm{m}^{2}\right)$ also exists along the exposed coastal and offshore areas of Alaska, with the greatest amounts appearing along the Aleutian Peninsula and Islands. Moderately high wind power (300-400 W/m $\mathrm{m}^{2}$ ) can be expected over the northern Great Plains and exposed sites along the Great Lakes and in Hawai

Seasonal patterns of wind power are similar to the annual patterns. The season(s) of maximum wind power is shown in Figure 2 and the analyses for each season are shown in Figures 3 through 6 . Over the eastern one-third of the nation, maximum wind power occurs during the winter and early spring. A spring maximum occurs over the Great Plains, the North-Central states, the Texas coast, most nonmountainous areas in the West (e.g., the basins and broad valleys), and offshore areas of central and southern California. Winter maxima occur over al1 mountainous regions, except for some areas in the lower Southwest where the spring wind power is about equally as large. A more complete description of the refined wind power analyses is given in Section 6 of this report.

The "large scale" regions of high and low wind power are similar to those identified in previous assessments. However, many significant differences in the wind power estimates and geographical distributions between this synthesis and the previous national assessments are evident (see Section 5). Further analyses of the data sets used in these assessments are not iikely to result in an improved national assessment. In the future, emphasis should be placed on separate regional analyses using data from all available sources for each region. 


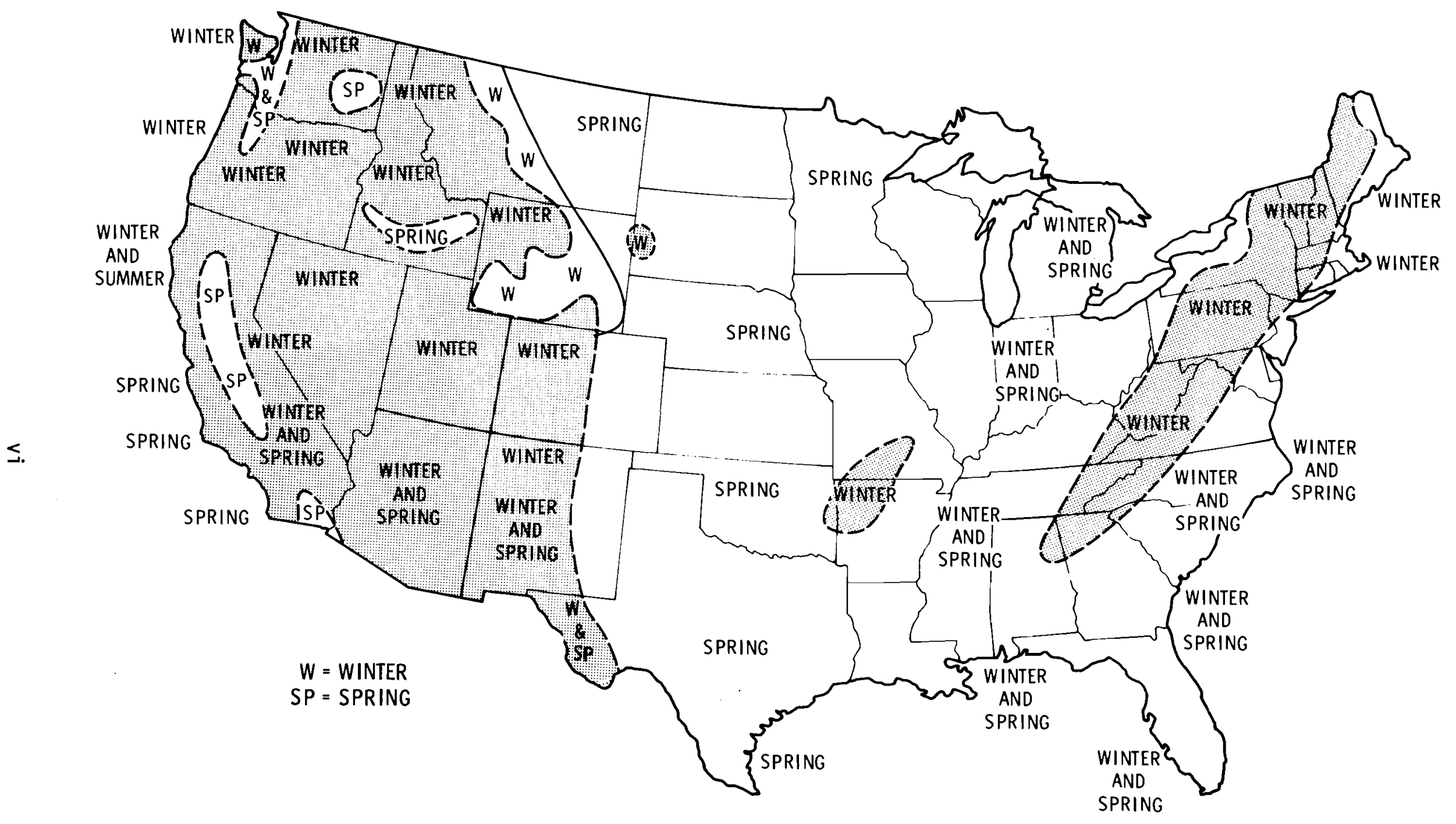

FIGURE 2. Season(s) of Maximum Wind Power. Over mountainous regions (shaded areas), the season(s) indicated is for exposed mountain sites. Seasons are abbreviated, where necessary, as follows: $W=$ winter, $S P=$ spring. 


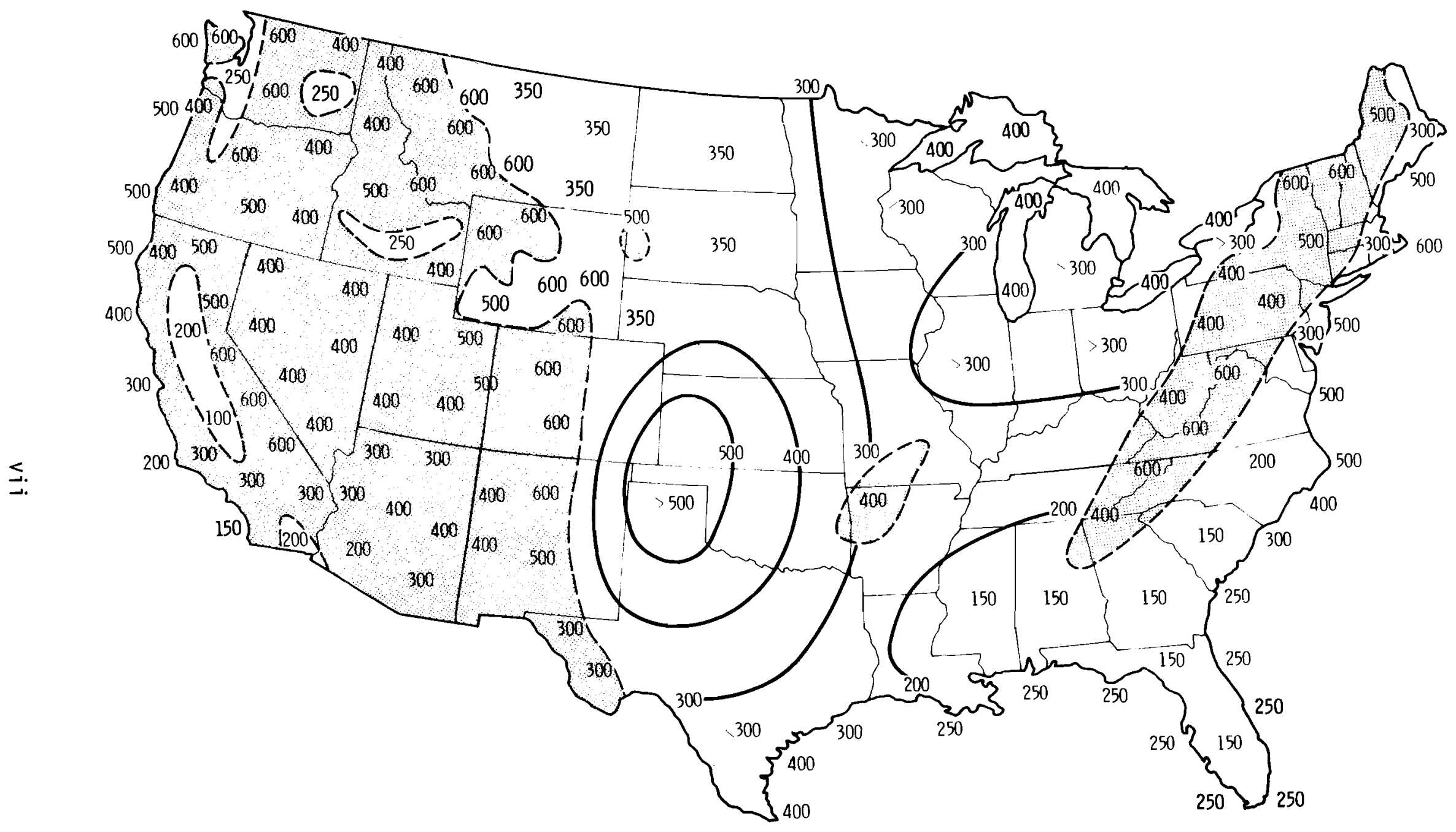

FIGURE 3. Winter - Average Wind Power $\left(W / \mathrm{m}^{2}\right)$ Estimated at $50 \mathrm{~m}$ Above Exposed Areas. Over mountainous regions (shaded areas), the estimates are lower limits expected for exposed mountain tops and ridges. 


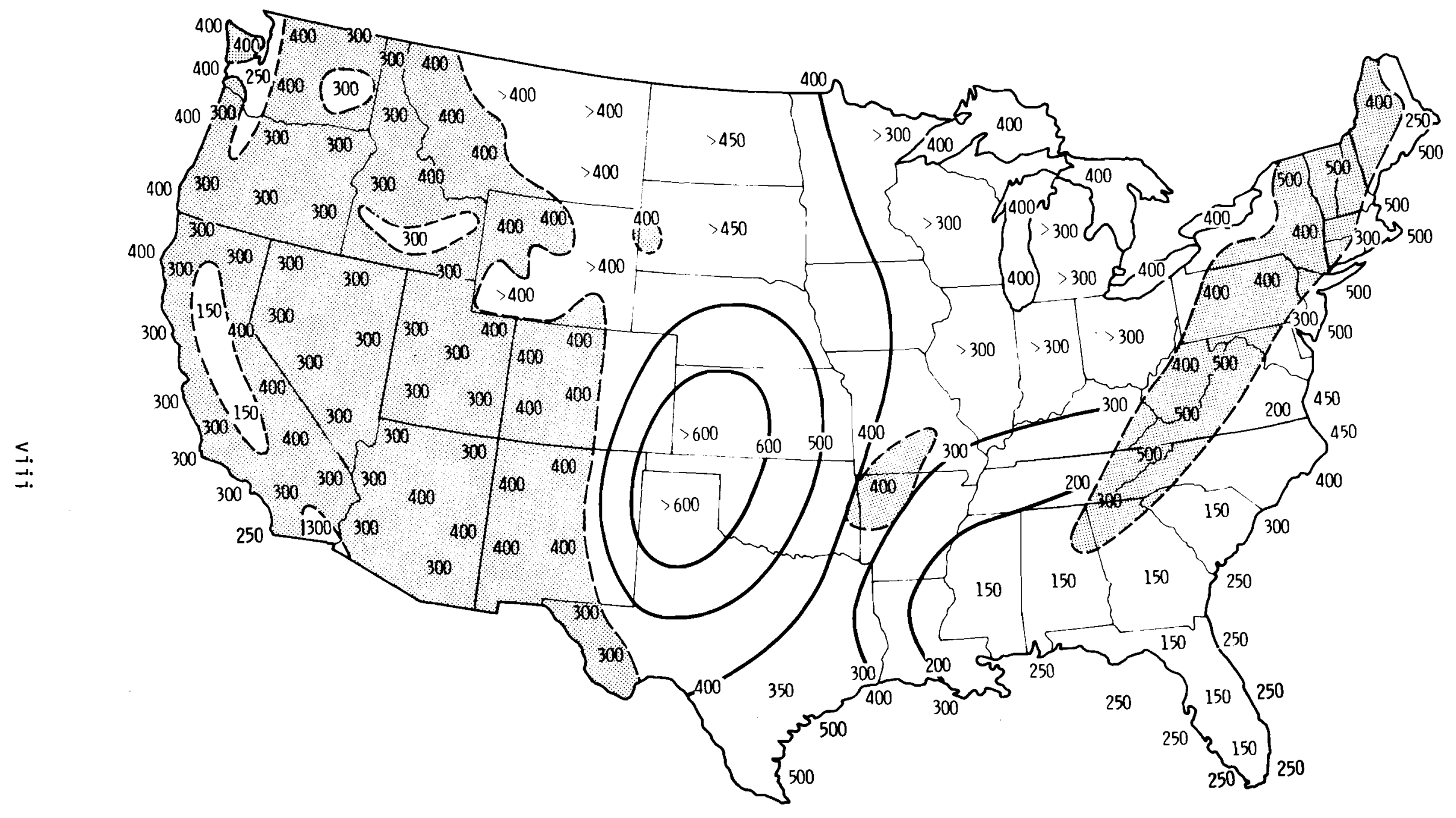

FIGURE 4. Spring - Average Wind Power $\left(W / \mathrm{m}^{2}\right)$ Estimated at $50 \mathrm{~m}$ Above Exposed Areas. Over mountainous regions (shaded areas), the estimates are lower limits expected for exposed mountain tops and ridges. 


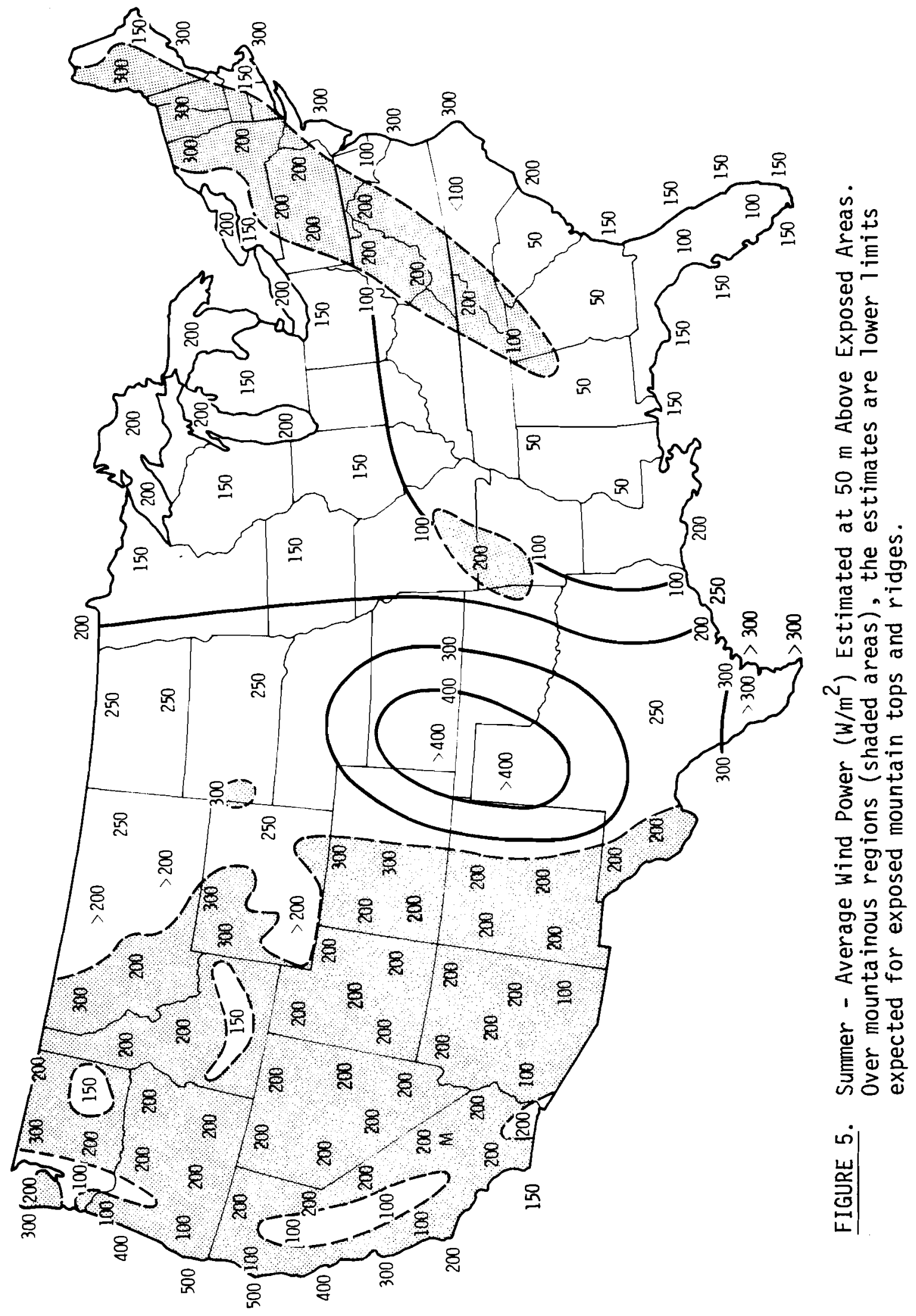




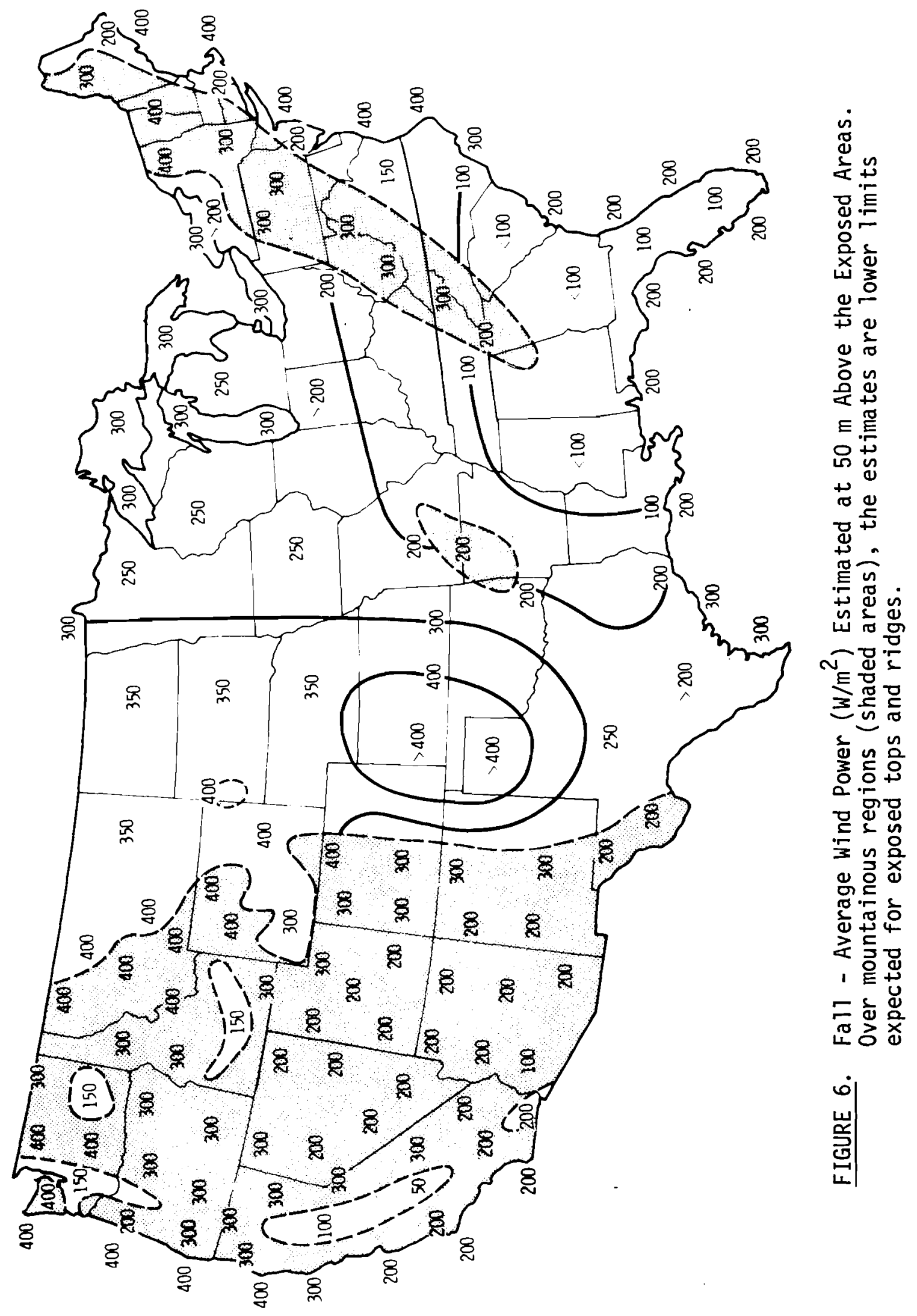




\section{CONTENTS}

SUMMARY

LIST OF FIGURES

LIST OF TABLES .

1. INTRODUCTION

2. TECHNIQUE FOR ESTIMATING WIND POWER • • • • • • • • • • . 5

3. TYPES OF WIND DATA SETS AND SUMMARIES AVAILABLE FOR

ASSESSING THE NATIONAL WIND POWER • • • • • • • • • • •

4. GENERIC FACTORS TO CONSIDER IN A NATIONAL WIND POWER ASSESSMENT . 1

4.1 ATMOSPHERIC DENSITY . . . . . . . . . . . . . . . 11

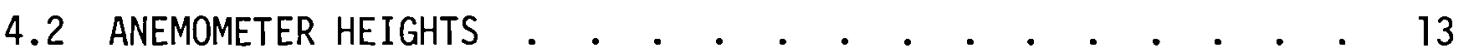

4.3 INFLUENCES OF MINOR VARIATIONS IN TOPOGRAPHY. . . . . $\quad$ • 14

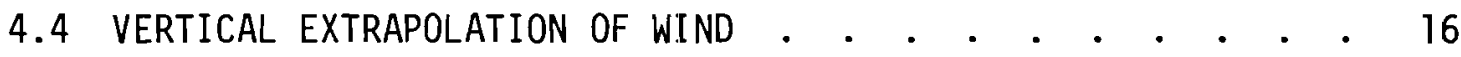

4.5 MOUNTAINOUS REGIONS . • . . . . . . . . . . . . . . . . 18

4.6 COASTAL AND OFFSHORE REGIONS . . . . . . . . . . . . . . 20

5. REVIEW OF THE EXISTING NATIONAL WIND ENERGY ASSESSMENTS - • • 21

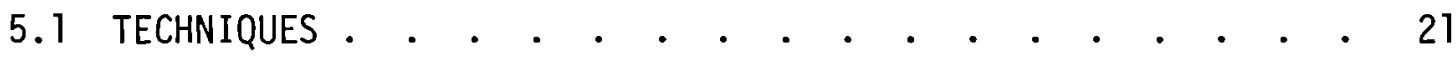

Surface Wind Data Employed. . . . . . . . . . . 21

Method of Estimating Surface Wind Power . . . . . . . 23

Adjustments for Anemometer Height Variations. . . . . 23

Adjustments for Atmospheric Density Variations . . . . . 24

Use of 150 m Level Rawinsonde Data . . . . . . . . 24

Vertical Extrapolation Techniques . • . . . . . . 25

Techniques Applied to Estimate Mountain Top

Wind Power . . . . . . . . . . . . . . . 26

Techniques Applied to Estimate Offshore Wind Power . . 26 


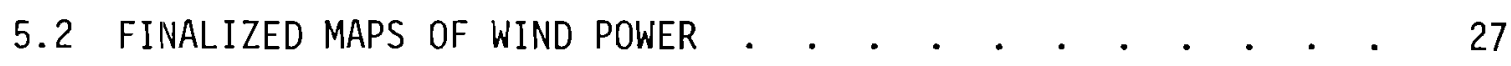

Sandia . . . . . . . . . . . . . . . . . 27

General Electric . . . . . . . . . . . . . 27

Lockheed . . . . . . . . . . . . . . . . . 28

5.3 SLIMMARY OF THE TYPES OF ERRORS AND UNCERTAINTIES . . . . . 29

6. THE REFINED ANALYSES OF NATIONAL WIND POWER. . . . . . . . • . 30

6.1 METHODS USED IN THE ANALYSES . . . . . . . . . . . . . 31

6.2 GEOGRAPHICAL DISTRIBUTIONS . . . . . . . . . . . . . . 34

Annual Pattern in the Contiguous U.S. . . . . . . . . 34

Seasonal Patterns of Wind Power in the

Contiguous U.S. • • . . . . . • . . . . . . . 35

Wind Power in Alaska . . . . . . . . . . . . . . 36

Wind Power in Hawaii. . . . . . . . . . . . . 36

Diurnal Variations of Wind Power . . . . . . . . . 37

7. CONCLUSIONS . . . . . . . . . . . . . . . . . . . 39

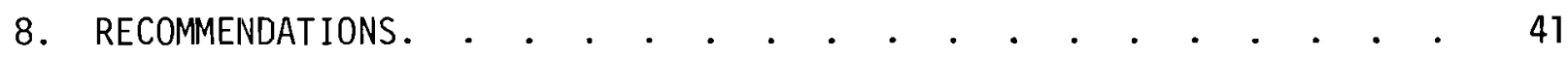

9. REFERENCES • • • • • • • • 


\section{FIGURES}

1 Mean Annual Wind Power $\left(W / m^{2}\right)$ Estimated at $50 \mathrm{~m}$ Above Exposed Areas . . . . . . . . . . . . . . . . . . iv

2 Season(s) of Maximum Wind Power . . . . . . . . . . . . vi

3 Winter - Average Wind Power $\left(\mathrm{W} / \mathrm{m}^{2}\right)$ Estimated at $50 \mathrm{~m}$ Above Exposed Areas . . . . . . . . . . . . . . . . . vii vi

4 Spring - Average Wind Power $\left(W / \mathrm{m}^{2}\right)$ Estimated at $50 \mathrm{~m}$ Above Exposed Areas... . . . . . . . . . . . . . . . viji

5 Summer - Average Wind Power $\left(W / \mathrm{m}^{2}\right)$ Estimated at $50 \mathrm{~m}$ Above Exposed Areas . . . . . . . . . . . . . . . . . . ix

6 Fall - Average Wind Power $\left(\mathrm{W} / \mathrm{m}^{2}\right)$ Estimated at $50 \mathrm{~m}$ Above Exposed Areas . . . . . . . . . . . . . . . . . $x$

7 The Percent Reduction of Wind Power with Elevation Due to Atmospheric Density . . . . . . . . . . . . . . 12

8 The Variation of Wind Power and Atmospheric Density with Temperature... . . . . . . . . . . . . . . . 13

9 Geographical Distribution of Area Where Local Variations in Terrain Elevations are Less Than $30 \mathrm{~m}(100 \mathrm{ft})$ Over Areas $9.6 \mathrm{~km}$ (6 miles) Across . . . . . . . . . . . . .

10 Comparison of Measured Mountain Summit Wind Speeds, $V_{m}$, to Estimated Free Air Wind Speeds, $V_{f}$ (from rawinsonde data) at the Same Height as the Summit . . . . . . . . .

\section{TABLES}

1 Annual Average Wind Power (Watts $/ \mathrm{m}^{2}$ ) at $50 \mathrm{~m}$ for Various Geographical Areas.

2 A Summary of the Criteria Used in the National Wind Energy Assessments by Sandia, General Electric, and Lockheed . . . . 22 


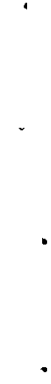




\section{INTRODUCTION}

The geographical distribution of the total available wind power over the United States has previously been described by Reed. ${ }^{1}$ Reed's report identified large-scale regions of high wind power potential over the United States and described seasonal variations in wind power. However, a need for an expansion and refinement of the initial national wind power assessment by Reed was evident. Reed's analysis did not adequately consider some important factors (see Section 4), e.g., atmospheric density variations with elevation, and height of the wind measurements above ground. As a component of the National Wind Energy Mission Analysis for the Energy Research and Development Administration (ERDA), two more recent national wind power assessments were made: an assessment by the Lockheed-California Company ${ }^{2}$ and an assessment by General Electric. ${ }^{3}$ A study has also been made (Justus et a1. ${ }^{4}$ ) showing the geographical distribution over the continental United States (based on wind summaries for 135 surface stations) of annual capacity factor values (ratio of average power output to rated power) for two types of wind-powered generators.

The main purpose of this study is to synthesize the national wind energy assessments by Sandia (Reed), Lockheed, and General Electric so that a consistent and representative analysis of the geographical distribution of the total wind power on a national scale can be demonstrated. Inconsistencies and discrepancies in the geographical distributions and estimates of wind power are apparent among the analyses, as shown in Table 1. The techniques, assumptions, data sets, and analysis methods used account for most of these differences. It was realized that more than just an extraction of the best features of existing assessments was needed. For example, where different data sets or different techniques give considerably different wind power estimates, an examination of the criteria used was essential to determine which estimates were more realistic. Much attention is given in this study to the representativeness of the wind speed distribution sumaries for typical wind turbine sites and how to best estimate the wind power for exposed areas in regions of different terrain types. Stations for which wind data are available are often located in sheltered areas and are not representative of exposed windier sites more suitable for wind turbines. 
TABLE 1. Annual Average Wind Power $\left(W / \mathrm{m}^{2}\right)$ at $50 \mathrm{~m}$ for Various Geographical Areas. These values were estimated from the national analyses made by each of the assessments.

\begin{tabular}{|c|c|c|c|}
\hline & Sandia & $\begin{array}{l}\text { General } \\
\text { Electric }\end{array}$ & Lockheed $^{c}$ \\
\hline Texas Panhandle & $450-650$ & $250-450$ & $400-990$ \\
\hline Eastern Kansas & $300-400$ & $200-300$ & $180-990$ \\
\hline Iowa & $250-350$ & $150-200$ & $290-673$ \\
\hline Eastern Dakotas & $350-450$ & $200-250$ & $300-812$ \\
\hline Southern Wyoming & $400-850$ & $250-500$ & $523-1030$ \\
\hline Lake Michigan & $200-250$ & $150-200$ & $210-840$ \\
\hline Indiana & $200-250$ & $100-200$ & $200-565$ \\
\hline Western New York & $200-350$ & $150-300$ & $140-1000$ \\
\hline Atlantic Coast (NY to NC) & $250-300$ & $400-600$ & $190-904$ \\
\hline Central Gulf Coast ( $L A$ to $A L$ ) & $150-200$ & $300-450$ & $170-220$ \\
\hline Texas Coast & $300-350$ & $250-300$ & $490-570$ \\
\hline Oregon Coast & $200-300$ & $400-600$ & $800-1610$ \\
\hline W. New Mexico Mountains & $N / A$ & $400-700$ & $190-340$ \\
\hline Arizona Mountains & $N / A$ & $100-200$ & $100-430$ \\
\hline
\end{tabular}

(a) At the time of this report, the final reports were not available for the General Electric and Lockheed assessments. Thus, these values are subject to change.

(b) Sandia's analysis was assumed to be for a $10 \mathrm{~m}$ height, and values were extrapolated to $50 \mathrm{~m}$ using a $1 / 7$ power 1 aw.

(c) Isodyns were not drawn. Hence, the lowest and highest values in each area were selected.

In a national wind energy assessment, perhaps the most important items are the finalized maps showing the geographical distribution of wind power. The maps should be easy to interpret and realistically identify areas of relatively high or low wind power. The wind power estimates should be given for a typical wind generator hub height. Hub heights range from about $15 \mathrm{~m}$ for small WECS to over $50 \mathrm{~m}$ for large WECS. Over regions of gently rolling, hilly, and mountainous terrain, the estimates should be given for the exposed terrain features, representative of potential wind turbine sites. 
In Section 2, the basic method used in calculating wind power from wind speed data is described. Section 3 describes some of the various types of wind data sets and summaries available from the National Climatic Center (NCC), National Oceanic and Atmospheric Administration, Asheville, NC, which can be used for evaluating wind power over the United States. Section 4 discusses the factors which should be considered in performing a national assessment of wind power. These include density variations, anemometer heights, terrain characteristics, techniques in the vertical extrapolation of winds, and the estimation of wind power over mountainous and offshore regions. A review of previous national wind energy assessments is presented in Section 5 . The refined analyses of the geographical distribution of seasonal wind power over the United States are described in Section 6, along with a discussion of the techniques and assumptions used in performing the analyses. 
.

- 


\section{TECHNIQUE FOR ESTIMATING WIND POWER}

The total power available from the wind passing through a unit area normal to the wind is

$$
P=\frac{1}{2} \rho v^{3}
$$

where $\rho$ is the atmospheric density in $\mathrm{kg} / \mathrm{m}^{3}, v$ is the wind speed in $\mathrm{m} / \mathrm{sec}$, and $P$ is the power in $W / m^{2}$. Since wind power is proportional to the cube of the wind speed, small increases in wind speed result in significant increases in wind power. An increase in the mean wind speed by a factor of 2 yields roughly 8 times the wind power. The wind speed at a site is affected by the surrounding environment, such as hills, trees, and buildings, and typically increases with height in the boundary layer. Therefore, selection of a site and height of the wind generator above the ground are two very important factors to consider for obtaining optimum wind power.

Because wind power varies as the cube of wind speed, the distribution of speed, rather than the mean speed, is needed to calculate the power resource. Determination of the wind speed frequency distributions typically require the use of hourly or three hourly wind speed data. Frequency distributions have been compiled by the National Climatic Center (NCC) for selected time periods for many of the surface stations in the U.S. which make wind measurements. However anemometer heights and locations varied considerably at many of the stations for the period of record over which these summaries were made. These variations can cause considerable errors in the wind power estimates, since a change in the anemometer height or location may give a significant difference in the wind power estimate (see Section 4.2).

Only mean wind speed summaries are readily available for many stations and for desired periods of record for which the anemometer heights are constant over the period. An empirical method developed by Widger ${ }^{5}$ and tested on six New England sites indicated that the actual wind power can be approximated within $\pm 20 \%$ by using only the mean wind speed. On the other hand, Baker and Hennessey ${ }^{6}$ show that accurately estimating the shape of the wind speed distribution is critical and that the method suggested by Widger is not usable if the wind speed distribution is highly skewed or deformed. 
They found that the actual annual wind power was underestimated by over $50 \%$ at some sites in the Pacific Northwest, using Widger's technique.

Wind energy per unit area is just the power times the time period; that is

$$
E=P \cdot \Delta t
$$

where $P$ is the power per unit area, $W / m^{2} ; \Delta t$ is the time period in hours; and $E$ is the energy per unit area, $W-h r / m^{2}$. One megawatt-hour $/ \mathrm{m}^{2} / y r$ is equivalent to approximately $114 \mathrm{~W} / \mathrm{m}^{2}$ in wind power. 


\section{TYPES OF WIND DATA SETS AND SUMMARIES AVAILABLE}

FOR ASSESSING THE NATIONAL WIND POWER

A11 meteorological data recorded by the National Weather Service, the Federal Aviation Administration, and the military services are retained at the National Climatic Center (NCC), Asheville, NC. A comprehensive report on the availability of data and sumarizations of land and marine surface wind measurements, upper level wind measurements, gusts, turbulence, and tower data has been done by Changery. ${ }^{7}$ The NCC is compiling an index of surface stations for which summaries of wind speed distributions are available.

Several types of surface wind speed distribution summaries available from the NCC are: 1) the wind speed frequency distributions for 758 stations originally compiled for Sandia Laboratories for the purpose of national wind power estimation,* 2) STAR program wind speed frequency distributions for over 300 stations, and 3 ) wind speed distribution summaries for Marsden squares and Navy Marine Areas based on ship measurements. Also, hourly wind data (three hourly since 1965) are digitized for over 1000 stations in the United States. (STAR programs are created from these digitized data.) The utilization of the above types of data and upper air data to assess the national wind power potential is briefly described below.

The Sandia tape of wind speed distributions was used in the national wind energy assessments by Sandia, General Electric, and Lockheed. As indicated in some of these assessments, these summaries have several major limitations: 1) periods of record vary considerably from station-to-station, ranging from 2 to 30 years or more, 2) anemometer heights often vary during the period of record for which the summaries are compiled, and 3 ) the number of wind speed classes vary from station-to-station, ranging from 3 up to as many as 16 . All of these factors--period of record, anemometer height, and number of wind speed classes--can lead to significant errors in wind power estimates for individual stations, so these summaries must be used with caution.

*Hereafter, this data set shall be referred to as the Sandia tape. 
The STAR (Stability Array) program gives the frequency distribution of wind speed versus wind direction for individual stability classes and usually for all classes combined. Thus, summaries without stability are available. These summaries are somewhat better in that the wind speed classes are identical for all stations and many of the summaries are for recent time periods (1960s and 1970s) when anemometer heights are generally constant over the time period. Al though the STAR program summaries have not been used in any of the national wind energy assessments, they would be a valuable supplement. These summaries have been generated from digitized hourly (or 3 hourly) data.

Wind speed distribution summaries for Marsden squares (areas of $1^{\circ}$ lat $i-$ tude by $1^{\circ}$ longitude) and Navy Marine Areas are useful for identifying relative patterns of wind power over offshore regions, but there are some uncertainties on the typical heights and overall accuracy of shipboard measurements and the application of this data to properly assess wind power in near coastal areas, i.e., exposed coastal sites and sites 5 to $10 \mathrm{~km}$ seaward.

Hourly (or three hourly) digitized winds appear to be the best set of data for use in obtaining representative wind power estimates. The period of record can be selected so that the anemometer height is constant, and errors associated with estimating the wind power from wind speed classes are eliminated since the wind power can be computed directly from the actual observations. However, the utilization of digitized data to compute wind power is more expensive than that of summarized data but certainly not unreasonable. Justus ${ }^{8}$ used this three-hourly digitized data for studies of wind power over the Great Plains and New England.

Low-level rawinsonde data for $150 \mathrm{~m}, 300 \mathrm{~m}$, and higher levels are summarized into wind speed classes in intervals of $5 \mathrm{~m} / \mathrm{sec}$ for 65 rawinsonde stations in the U.S. The summaries are given separately for $00 Z$ and $12 Z$ observation times and, mostly, for a 5-year record period. (These data were originally summarized by the NCC for a study by Holzworth. ${ }^{9}$ ) Flow patterns are usually more coherent at these levels, and topography and roughness effects are much smaller. However, the chief limitations on the use of this rawinsonde data are that 1) the twice-daily observations may not be sufficient (e.g., they cannot account for the influence of diurnal variations), 2) the stations are too widely scattered, 3) the wind speed intervals are very broad, 
and 4) there are uncertainties regarding the accuracy of the rawinsonde wind speeds for $150 \mathrm{~m}$ and their extrapolation down to $50 \mathrm{~m}$.

For estimating upper air wind power, useful data sources are the climatological maps by Crutcher $^{10}$ and statistical parameters of upper winds at $850 \mathrm{mb}$ (near $1500 \mathrm{~m}$ ) and $700 \mathrm{mb}$ (near $3000 \mathrm{~m}$ ). Another data source which can be used to estimate upper air wind power over the U.S. is gridded 12 hourly upper air data for standard levels (e.g., 850, 700, $500 \mathrm{mb}$ ), stored on tape at the National Meteorological Center (NMC), Suitland, MD. Upper air wind power is applied to estimate the wind power potential over mountainous regions. 


\section{GENERIC FACTORS TO CONSIDER IN A NATIONAL WIND POWER POWER ASSESSMENT}

There are many factors which need to be considered in obtaining representative estimates of wind power and its geographical distribution. One important factor that should be considered is the reliability of the wind speed data. How good is the anemometer exposure, the accuracy of the measurements, and the manner in which the data is registered? For aviation purposes, errors of just $1 \mathrm{~m} / \mathrm{sec}$ may not matter that much. However, the difference in wind power between a $4.4 \mathrm{~m} / \mathrm{sec}(10 \mathrm{mph})$ and $5.6 \mathrm{~m} / \mathrm{sec}(12.5 \mathrm{mph})$ wind speed is $100 \%$. Thus, minor variations in wind speed due to instrument exposure or accuracy can result in substantial errors in the wind power estimates.

Other primary considerations in the accuracy of wind power estimates include atmospheric density variations with elevation and temperature, height of wind measurements above ground, terrain influences and local height variations in topography, representativeness of the available wind data to exposed wind turbine locations, vertical extrapolation of wind power, influence of the number of wind speed classes, techniques for estimating wind power over mountainous and offshore areas and areas of sparse data, techniques for using rawinsonde data, and methods of interpolation and analysis used for producing the finalized maps. This last item, if not properly done, can itself result in major misrepresentations in the geographical distributions of wind power. Some of these factors, such as instrument exposure, are uncertainties which cannot be accounted for in the wind power estimates but should be recognized as sources of errors. Some of the more important generic factors are discussed below.

\subsection{ATMOSPHERIC DENSITY}

Wind power is directly proportional to atmospheric density, which decreases with increasing height and temperature. At sea level the standard density, in the U.S. Standard Atmosphere, is $1.225 \mathrm{~kg} / \mathrm{m}^{3}$. Figure 7 shows the relationship between height, density, and percent reduction in wind power. Wind power would be overestimated for much of the Great Plains and western mountains (e.g., 17\% at Cheyenne, WY) by using sea level density in the calculation. 


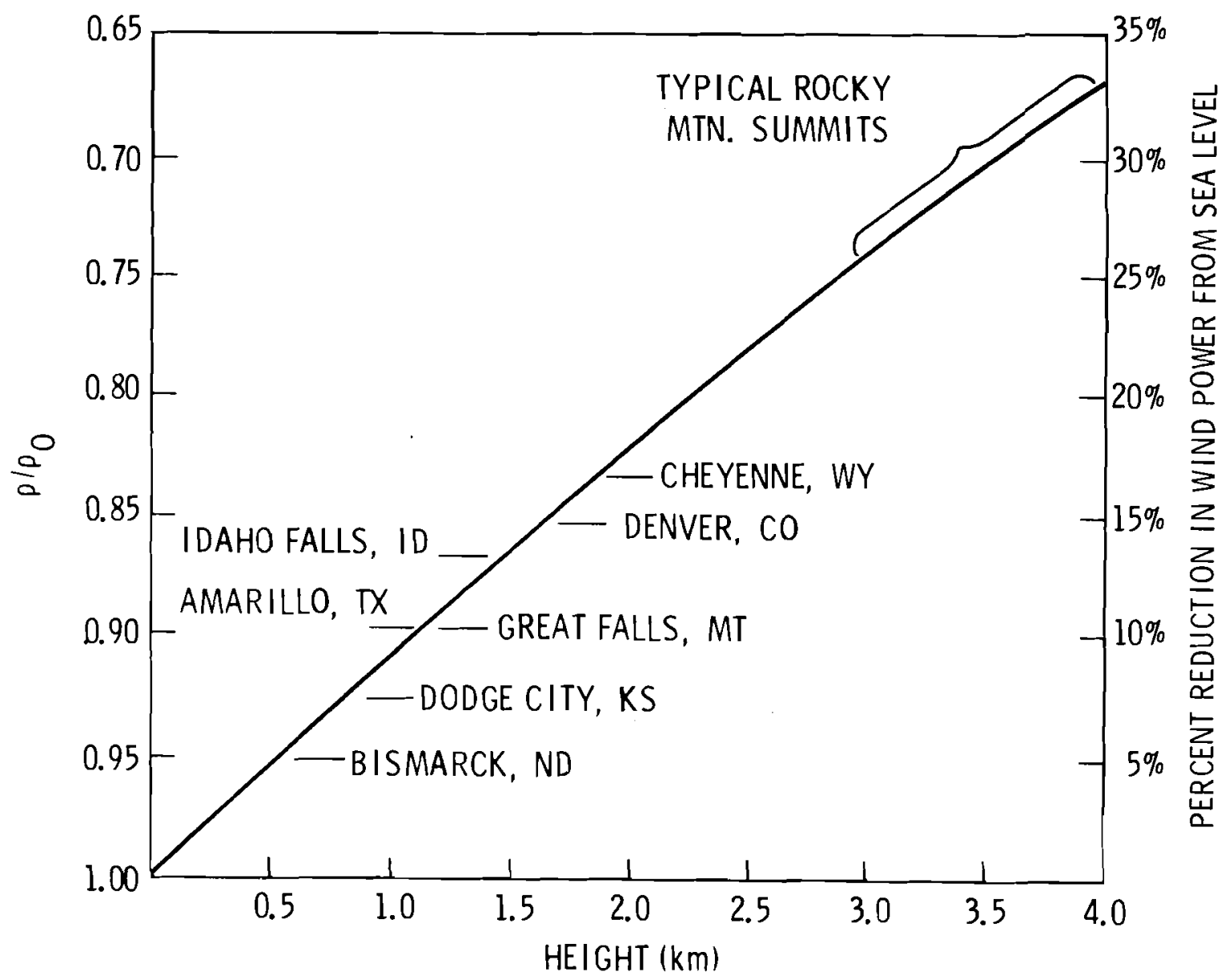

FIGURE 7. The Percent Reduction of Wind Power with Elevation Due to Atmospheric Density. Density ratios are given with respect to standard sea level density, $\rho_{0}\left(1.225 \mathrm{~kg} / \mathrm{m}^{3}\right)$.

Figure 8 shows the effect of temperature variations on wind power. The national assessment by Lockheed ${ }^{2}$ indicated that mean monthly atmospheric densities differ from the standard density at that elevation by generally less than $5 \%$ and rarely greater than $10 \%$, based on computations for 7 stations well distributed in elevation and location throughout the conterminous United States. Neglecting seasonal variations in temperature results in the summer wind power being slightly overestimated and the winter wind power being underestimated. Thus, the annual wind power would be underestimated for regions where the colder months are the windier months. 


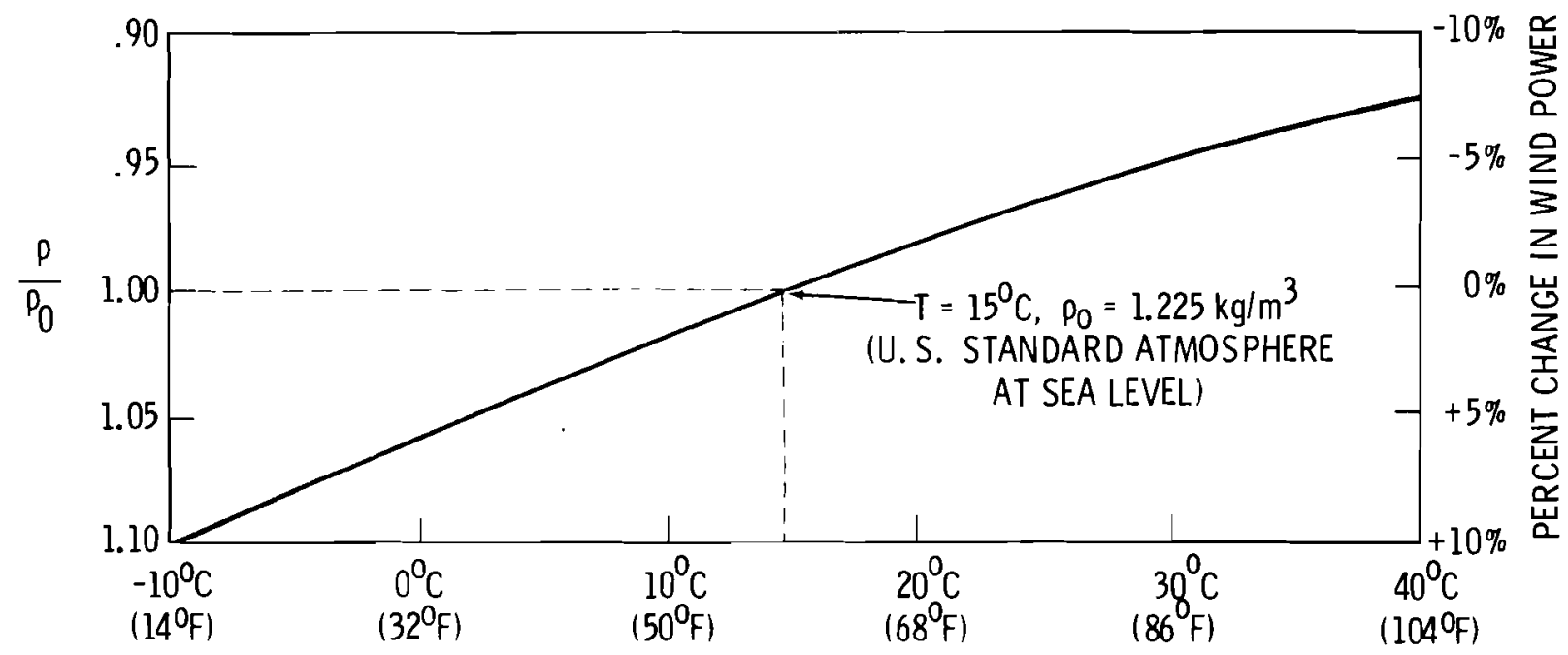

TEMPERATURE

FIGURE 8. The Variation of Wind Power and Atmospheric Density with Temperature. Density ratios are given with respect to sea level density for the U.S. Standard Atmosphere at $15^{\circ} \mathrm{C}$.

\subsection{ANEMOMETER HEIGHTS}

Anemometer heights at National Weather Service stations have varied considerably over the years. Typical heights of the wind sensors above the ground among the stations have ranged from $4 \mathrm{~m}$ to $60 \mathrm{~m}$. Nevertheless, $10 \mathrm{~m}$ is often assumed to be the standard anemometer height. Many anemometers have been located on airport terminals or buildings. Within towns and cities, anemometers may have been placed on buildings to obtain better exposure to the winds. However, the building itself may cause an obstruction to the air flow at the anemometer location, depending on the height of anemometer above the roof of the building, the shape of the building, and the location of the anemometer on the building top. Thus, the exposure of an anemometer should not be assumed to be unobstructed to air flow until certain site characteristics are properly evaluated.

At the majority of stations, anemometer heights and locations were often changed during the period of time for which summarized wind speed data and/or frequency distributions are available. Wind power is very sensitive to changes in anemometer height and is typically 30 to $60 \%$ greater at $20 \mathrm{~m}$ than at $10 \mathrm{~m}$ (see Section 4.4 - Vertical Extrapolation of Wind). Thus, aside from 
all other factors, the temporal and spatial variations in anemometer heights make it very difficult to obtain representative estimates of wind power utilizing available wind speed distribution summaries.

Beginning in the late 1950 s and throughout the 1960s, the National Weather Service (NWS) relocated anemometers to approximately $6 \mathrm{~m}$ (20 ft) above the ground. The relocations were completed by 1965 for most of the stations.

A history of the anemometer heights for most NWS stations in the U.S. is included with Local Climatological Data (LCD), a publication available from the NCC. A report by Coty et al. 11 ists anemometer heights for 478 of the stations on the Sandia tape and presents the wind power tabulations for these stations. However, the anemometer heights varied over the period of record or were not known for many of the stations, and therefore, were "assumed" to be $10 \mathrm{~m}$ at those stations. If the actual heights were much greater than $10 \mathrm{~m}$ $($ e.g., 15 to $20 \mathrm{~m})$, this assumption could result in the wind power being considerably overestimated for the $10 \mathrm{~m} \mathrm{level}$ and consequently for all other levels.

\subsection{INFLUENCES OF MINOR VARIATIONS IN TOPOGRAPHY}

Less than $20 \%$ of the United States can be considered flat terrain, that is, with local relief varying no more than $30 \mathrm{~m}(100 \mathrm{ft})$. Figure 9 shows the geographic distributions of these areas. (This figure was constructed from a map in the National Atlas of the United States.12) Areas for which $10 \mathrm{ca} 1$ relief are defined are square units $9.6 \mathrm{~km}(6 \mathrm{mi})$ across. Thus, most of the nonmountainous area of the U.S. is classified as gently rolling to hilly terrain, with local relief variations greater than $30 \mathrm{~m}$.

Very minor changes in elevation can produce significant differences in wind power. Over regions of gently rolling terrain (defined here as having local relief variations of 30 to $100 \mathrm{~m}$ ), many stations taking wind measurements are located in the lower areas which are not representative of the higher exposed elevations more suitable for wind turbines. Increases of $1 \mathrm{~m} / \mathrm{sec}$ in the mean wind speed may give $50 \%$ to as much as a $100 \%$ increase in available wind power for mean wind speeds of 3 to $7 \mathrm{~m} / \mathrm{sec}(7$ to $15 \mathrm{mph}$ ). An excellent example is Rochester, Minnesota, located in the rolling terrain of southeast 


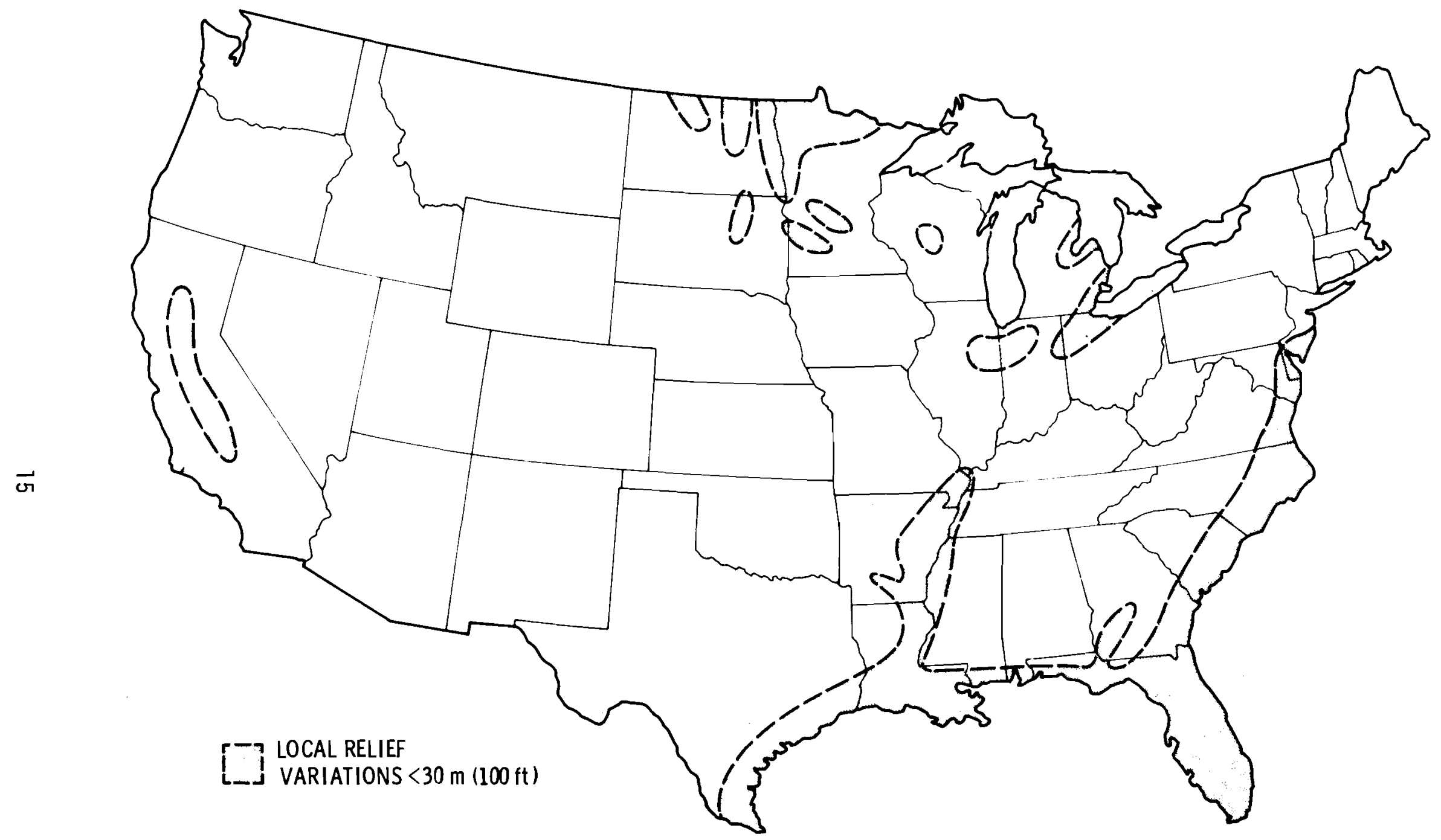

FIGURE 9. Geographical Distribution of Area Where Local Variations in Terrain Elevations are Less than $30 \mathrm{~m}(100 \mathrm{ft})$ Over Areas $9.6 \mathrm{~km}$ (6 miles) Across 
Minnesota. The Rochester National Weather Service (NWS) station is located on a ridge about $100 \mathrm{~m}$ (300 ft) higher elevation than the city and lower elevations in the local vicinity. The average annual wind speed at the Rochester NWS is $5.7 \mathrm{~m} / \mathrm{sec}(12.7 \mathrm{mph})$, which is 1 to $2 \mathrm{~m} / \mathrm{sec}$ (2 to $4 \mathrm{mph}$ ) greater than for any other NWS station within a $250 \mathrm{~km}$ (150 mile) radius. (These records are based on annual wind speed summaries from 1965 to 1975, for which a11 anemometer heights have been standardized to approximately $6 \mathrm{~m}$.) Correspondingly, wind power at Rochester is 50 to $100 \%$ greater than that at surrounding stations. Thus, Rochester is the only NWS station in this region of gently rolling terrain which appears to have wind power typical of exposed areas representative of probable WECS sites.

Therefore, the elevation of the station with respect to the elevation of the surrounding terrain in the area should be considered to identify those stations which are representative of probable WECS sites. An analysis based only on an average of all the station values within an area will reflect the influences of the relative elevation exposure of the majority of stations.

An alternate method to estimate the wind power at the average height of the exposed areas over regions of rolling and hilly terrain is to utilize low-level rawinsonde data and extrapolate the values to the specified terrain heights. However, there are limitations on the use of rawinsonde data to estimate wind energy, as previously described (Section 3).

\subsection{VERTICAL EXTRAPOLATION OF WIND}

In the surface boundary layer, there are many factors which influence the variations of wind speed with height above ground, such as terrain roughness, atmospheric stability, and wind speed. Two relationships are frequently used to extrapolate the wind speed with height. One is the logarithmic velocity profile

$$
\frac{v_{2}}{v_{1}}=\frac{\ln \left(z_{2} / z_{0}\right)}{\ln \left(z_{1} / z_{0}\right)}
$$


where $V_{2}$ and $V_{1}$ are the wind speeds at heights $Z_{2}$ and $Z_{1}$, respectively, and $Z_{0}$ is the surface roughness length. The logarithmic profile is suitable for neutral stability conditions and high wind speeds. The second relationship is the power law profile.

$$
\frac{v_{2}}{v_{1}}=\left(\frac{z_{2}}{z_{1}}\right)^{\alpha}
$$

where $\alpha$ is a dimensionless exponent whose value may depend on the wind speed, atmospheric stability, and surface roughness. Since wind power is related to the cube of wind speed, the exponent becomes $3 \alpha$ for wind power.

The power law profile can also be applied for long-term averages. Reed 1 indicated that a value of $1 / 7$ for $\alpha$ is reasonably valid for long-term averages. Justus $^{13}$ estimated the average value of $\alpha$ as $0.23 \pm 0.03$, based on an examination of tower data at four sites in different areas of the United States. Justus' and Reed's studies showed that the height variation of wind speed is a function of the mean wind speed and height of the wind measurements, and relationships were developed to estimate $\alpha$ as a function of the wind speed and anemometer height. Basically, these relationships assume that the value of $\alpha$ decreases as the mean wind speed increases; that is, the increase of wind speed with height is not as great for higher wind speeds.

None of these previously mentioned values of a approximate the data very well at all tower sites; e.g., Drexel University/WFIL-TV tower data in Phildelphia, Pennsylvania shows $\alpha=0.34 .^{14}$ The extreme interstation variability in the surface wind speeds, even over homogeneous regions such as the Midwest and Great Plains, explains much of the variability in the mean values of $\alpha$. Consequently, it is difficult to justify using one value of $\alpha$ over another for the extrapolation of winds on a national scale. Moreover, values of $\alpha$ for exposed locations representative of probable WECS sites may be considerably different from those evaluated from available tower data. Nevertheless, some assumptions regarding the vertical variation of wind speed (and energy) must be made to extrapolate the wind energy to a wind generator hub height. 
Listings of tall instrumented towers have been compiled by Cormier ${ }^{14}$ and Wallace. 16 An abundant supply of tower wind data also exists for nuclear and coal-fired power plants throughout the country. A report on wind data summaries collected on towers at nuclear power plants in the U.S. has been prepared by Verholek. ${ }^{17}$ These data sources can be used to gain greater insight into the height variation of wind speed with regard to terrain, climatological, and surface roughness characteristics.

\subsection{MOUNTAINOUS REGIONS}

Upon examining the few available studies and data summaries for mountain summit winds, perhaps the best way to describe the relationship between the free air wind speed and mountain summit wind speed is "highly variable and complex." On some mountain summits the mean wind speed may be greater than the free air wind speed, while on others it may be less than $30 \%$ of the free air wind speed.

Wah $1^{18}$ evaluated the wind speed records for six mountain sulrmits ranging in elevation from about $800 \mathrm{~m}$ to $3000 \mathrm{~m}$, all located in Europe. The values for individual summit speeds ranged from less than $30 \%$ of the free air wind speed, where the surrounding terrain appeared to induce high frictional effects, to $80 \%$ or more for wel1-exposed summits subject to jet action. Figure 10 shows the average typical summit speed versus free air speed for different percentiles. The figure indicates that summit wind speeds are usually less than free air wind speeds at the summit height (except for low wind speeds), but summit wind speeds are less than one-half the free air wind speeds in only about $25 \%$ of the cases. Thus it appears that on the average, summit wind speeds are about 60 to $70 \%$ of the free air speed for wind speeds greater than $8 \mathrm{~m} / \mathrm{sec}$. However, Wahl's analysis also indicates that the relationship between summit speed and free air speed at summit height is reasonably independent of the height of the summit, as relatively low peaks sometimes have greater mean wind speeds than higher peaks. 


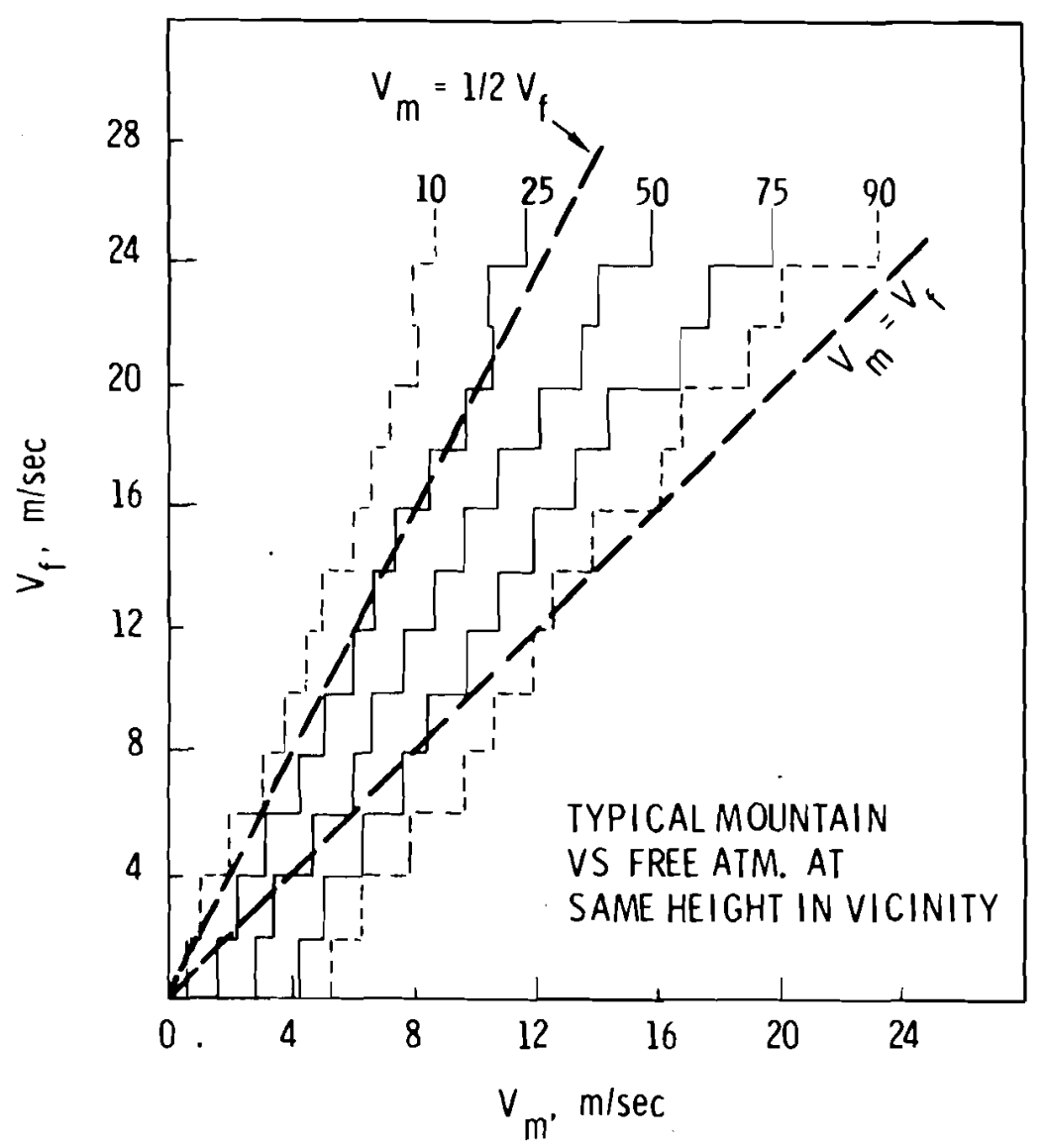

FIGURE 10. Comparison of Measured Mountain Summit Wind Speeds, $V_{m}$, to Estimated Free Air Wind Speeds, $V_{f}^{m}$ (from rawinsonde data) at the Same Height as the Summit. Mean frequency distributions for $V_{f}$ classes are indicated for different percentiles from 10 to 90 (after Wahl, 1966). Lines for $V_{m}=V_{f}$ and $V_{m}=1 / 2 V_{f}$ are included.

Pristov ${ }^{19}$ has also examined the relationship of free air speed to mountain summit wind speeds. For three mountain summits in the height range of 2000 to $3000 \mathrm{~m}$, his results indicate that wind speeds on isolated mountain ridges are not as turbulent or gusty as wind speeds on mountains within mountainous terrain. Wind speed records for a few mountain locations throughout the U.S. also indicate a complex relationship between free air speed and summit speed. 2,3

Thus, the wind power available on mountain tops appears to depend just as much on the shape and alignment of the mountains and the height of the surrounding terrain as it does on the height of the mountains. In the West, 
many lower isolated ridges may have as much or more usable wind power as the higher mountain ranges. Gaps or saddles between mountains are often known to have strong winds. Wind tunnel modeling studies have been performed to examine the influence various slope geometries and atmospheric stratifications have upon flow over ridges. 20

\subsection{COASTAL AND OFFSHORE REGIONS}

In coastal regions, the mean wind speeds are typically greater over the ocean than over land, primarily due to greater surface friction over land. The wind power just offshore and at exposed coastal sites, such as capes and points, may be a factor of 2 or more greater than the wind power calculated for a coastal town. The wind measurements for most coastal towns are made too far inland (1/2 km or more) or along sheltered areas, such as bays or inlets, to be representative of the wind speeds for windier coastal and offshore areas. Along coastal regions of rough terrain, such as that of Maine and the Pacific coast states, this decrease of wind speed from the coast inland is substantially greater. An important factor to consider at a coastal site is whether the prevailing winds come from a direction over the water or over the land. Sites where the prevailing winds come over the water are normally windier than sites where the prevailing winds come over land. For example, the east shore of the Great Lakes should have greater wind power than the west shore, since prevailing winds are generally from a westerly component.

Representative wind data for exposed coastal sites are very limited. offshore mean wind speed distributions based on ship observations are probably more applicable to exposed coastal sites than are most of the speed distributions from coastal towns, even though the ship observations are averaged over large offshore areas extending $100 \mathrm{~km}$ or more seaward. However, ship wind data should be used with caution due to uncertainties in the height of the wind measurements, the locations of the measurements within the area, and the accuracy and frequency of the measurements. 


\section{REVIEW OF THE EXISTING NATIONAL WIND ENERGY ASSESSMENTS}

Three wind energy assessments have been performed to evaluate the geographical distribution of total wind power over the United States. They are: an assessment by Reed ${ }^{1}$ of Sandia Laboratories, an assessment by Lockheed, ${ }^{2}$ and an assessment by General Electric (GE). ${ }^{3}$ The Sandia study was completed before the other studies began and provided a data base for them. A review of these assessments reveals discrepancies and inconsistencies in the geographical distributions of wind power and magnitude of the estimates (Table 1). The major problems facing all the assessments were how to deal with the enormous interstation variability in surface wind power estimates and how to estimate the wind power in mountainous and offshore regions and in regions of sparse data. These problems lead to most of the discrepancies and inconsistencies.

Table 2 summarizes the primary data sets or summaries, the techniques applied, the assumptions made, and the kinds of analyses performed in each assessment. This chapter is broken into two parts--one describing the techniques and data applied to estimate the wind power and one describing the national analyses produced.

\subsection{TECHNIQUES}

Surface Wind Data Employed

A11 three assessments used the same source of surface wind data--the Sandia tape of wind speed frequency distributions. The General Electric and Lockheed assessments were selective, though, in choosing the stations to be utilized. Lockheed eliminated those stations with "limited data," i.e., just 3 wind speed classes or with fewer than 4000 total observations in any month. This selection process provided a minimum of six years' observations. (However, wind power estimates for many of the stations with "limited data" that showed relatively high wind power were included on their maps of annual average wind power density.) General Electric used few stations with less than 5 wind speed classes, and "over the continental U.S., emphasis was given to the use of first order National Weather Service stations." Thus, GE used considerably fewer surface stations than Lockheed, but their assessment was based primarily on rawinsonde data. 


\section{TABLE 2. A Summary of the Criteria Used in the National Wind Energy Assessments by Sandia, General Electric, and Lockheed}

\section{Surface wind data used \\ No. of stations used \\ for surface analysis \\ Method of estimating \\ wind power \\ Accounted for varia- \\ tion in a nemometer \\ heights \\ Accounted for density \\ variations with sta- \\ tion elevation \\ Low-leve 1 rawinsond \\ data, e.g., $150 \mathrm{~m}$}

Sandia
Sandia wind speed frequency
distributions
758 (total available)
$V^{3}$ - median of wind speed
class
No
No
Not used
Suggests l/7 power law.
Different methods discussed
Climatological naps by
Crutcher
No. Sea level density used
850 mb power assumed typical
of Eastern mountains;
W00 mb power typical of
Coastal stations on Sandia
tape
Surface and upper air iso-
dyns (watts/m2), values
smoothed objectively by geo-
metric averaging. Annual
and seasonal averages for
surface; seasonal for upper
air

\section{General Electric}

Sandia wind speed frequency distributions

Not given. Primarily first order stations

$v^{3}$ - median of wind speed class

No. Heights as sumed to be $10 \mathrm{~m}$

Estimated wind power at 150 $m$ from frequency distribution for 65 stations.

Annual estimate only for $00 z$ Extrapolated downward from. $150 \mathrm{~m}$ to $50 \mathrm{~m}$ using empirical procedure

Climatological maps by Crutcher

Yes

Accounted for upper air density

Method of estimating mounta in top wind

power

Coastal and of fshor wind data used

Types of nationa? analyses made

Assumed $V_{m}=V_{f}$ thus $P_{m}=P_{f}$ $m$ - mountian, $f$ - free air

Ship wind data for Marsden squares and Navy Marine areas

I sodyns $\left(\mathrm{kmh} / \mathrm{m}^{2} / \mathrm{yr}\right)$ for surface, $150 \mathrm{~m}$ level, upper air.

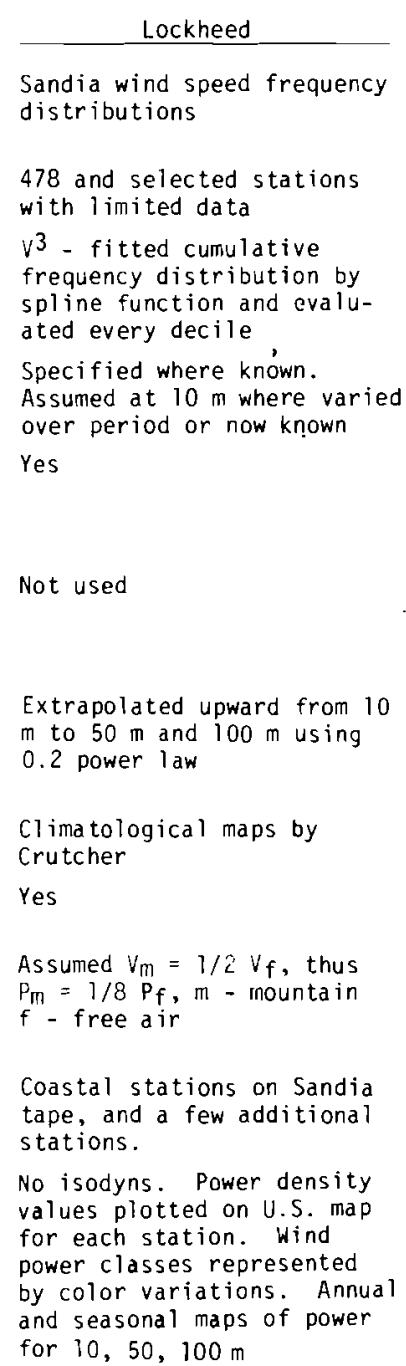

Many additional surface wind summaries and data sets are available

Median of class overestimates wind power by $7 \%$, on the average

Anemometer heights vary from 6-60 m. Standard height became $6 \mathrm{~m}$ in 1960s

Use of sea level density overestimates wind power by 8.5 - $9 \%$ per $\mathrm{km}$ increase in elevation

Use of this data underestimates wind power by 30-60\%

Extrapolating upward to $50 \mathrm{~m}$ using 0.2 power law gives 32 more energy than $1 / 7$ power law and $50 \mathrm{in}$ level. Subjective type analysis. Annual averages only. sea level density

Relation of mountain top highiy variable, ranging from $<1 / 8$ to $>1$

Many coastal stations are not sites

Discrepancies are found in the energy patterns and estimates
Density at $3 \mathrm{~km}$ is $<75 \%$ of power to free a ir power is representative of exposed 
Additional wind summaries and data sets are available that were not utilized in the national assessments, including hourly (or 3 hourly) digitized wind data.

\section{Method of Estimating Surface Wind Power}

Sandia and GE calculated wind power from wind speed frequency distributions using the midpoint wind speed of each class. General Electric found that wind power calculations based on the median wind speed of each class was consistently larger (from $3.2 \%$ to $10.5 \%$ for the seven stations evaluated) than that calculated from individual hourly wind speeds. These were all stations with 11 wind speed classes. However, Reed indicated that using the median of wind speed classes do not cause more than a couple percent error in most cases.

Lockheed's study shows that as the number of wind speed classes decreases, the percent error in wind power increases. A total of 128 stations on the Sandia tape have only three wind speed classes and 263 stations have six classes or fewer. The wind power estimated from these summaries is typically $10-30 \%$ high when compared to estimates computed from actual hourly observations.

Lockheed did not use the midpoint of wind speed classes to calculate wind power. Instead, the frequencies of wind speed, grouped into classes, were accumulated. This cumulative distribution was fitted by spline functions and evaluated at every decile. Wind power was obtained by cubing the percentiles of wind speed. However, the differences in the wind power estimates based on this technique and the midpoint of classes are usually less than $5 \%$. Adjustments for Anemometer Height Variations

Only Lockheed conducted a survey of anemometer height data for all the stations used. Wind speeds, where anemometer heights were known, were adjusted to $10 \mathrm{~m}$, and from that level to the $50 \mathrm{~m}$ and $100 \mathrm{~m}$ levels using a power law formula. In their report they state that: "Stations for which anemometer heights were not known, or for which the heights varied during the reported period, an initial height of $10 \mathrm{~m}$ was assumed." Prior to $1960 \mathrm{~s}$, typical anemometer heights were mostly 10 to $40 \mathrm{~m}$ above ground, as the anemometers were often located on buildings and airport terminals. The 0.2 power law coefficient for wind speed (used by Lockheed) results in 
$52 \%$ greater wind power at $20 \mathrm{~m}$ than that at $10 \mathrm{~m}$. Thus, assuming a $10 \mathrm{~m}$ anemometer height for those stations for which the anemometer heights varied over the record period or were not known may result in a significant overestimation of the wind power at the $10 \mathrm{~m} \mathrm{level}$ and, subsequently, at the $50 \mathrm{~m}$ level. However, even if the anemometer heights are standardized to $10 \mathrm{~m}$ from the actual heights, uncertainities may exist regarding the instrument exposure and effects of the building on the air flow which could cause large errors in the estimates.

With this variability and uncertainty in the heights and exposure of the anemometers, it is difficult to obtain representative estimates of wind speed, and therefore wind power. This explains much of the interstation variability in the wind power estimates. One solution is to consider only wind speed data from the 1960s and 1970s when anemometer heights are constant and instrument exposure is generally good. (During the late 1950s and early 1960s, most airport anemometers were moved to $6 \mathrm{~m}$ above the ground and placed away from buildings.) This data has been digitized in 3-hourly intervals and is available on tape from the National climatic Center. Thus, utilization of this data source would substantially reduce errors caused by uncertainties in anemometer height and exposure.

Adjustments for Atmospheric Density Variations

Atmospheric density variations with station elevations were accounted for in the Lockheed study but not in the GE and Sandia assessments. Neglect of density variation results in an overestimation of wind power by about $9 \%$ for every $1 \mathrm{~km}$ (3000 ft) elevation above sea level (Figure 7). Thus, the use of sea level density in the GE and Sandia assessments results in station wind power estimates that are 5 to $20 \%$ too high over much of the Great Plains and high basins of the West.

Use of $150 \mathrm{~m}$ Level Rawinsonde Data

General Electric used $150 \mathrm{~m}$ level rawinsonde summaries to obtain wind power estimates at $150 \mathrm{~m}$ and extrapolated these values down to $50 \mathrm{~m}$. Their $50 \mathrm{~m}$ annual analysis is based only on $00 Z$ rawinsonde observations. However, GE also analyzed monthly values for 20 stations at both $00 z$ and $12 z$ and stated in their report that "the pattern of energy distribution shown and the relative magnitude of the maxima and minima are validly represented by the $00 z$ analyses alone." 
We conducted a brief comparison of $150 \mathrm{~m}$ wind speeds for $00 Z$ and $12 Z$ and found that including the 122 winds in the analysis would increase the wind power estimate over the southern Great Plains and decrease the wind power slightly over much of the rest of the U.S. Thus, our analysis shows that the relative magnitudes are modified, but the large scale patterns of wind power for $00 Z$ and $12 Z$ remain similar, with distinct maxima showing up over the Great Plains just east of the Rockies, along the Northeast coast and south Texas coast. However, because of the large spacing between stations, only gross features can be depicted wịth these data.

Vertical Extrapolation Techniques

Each assessment used the power law formula to adjust the wind speeds and wind power to different levels. Reed suggests using a 1/7 power 1 aw; Lockheed extrapolated the surface wind speeds for $10 \mathrm{~m}$ up to $50 \mathrm{~m}$ and $100 \mathrm{~m}$ using a 0.2 power. Wind power estimates for $50 \mathrm{~m}$ based on a 0.2 power law are $32 \%$ higher than estimates based on a 1/7 power $1 \mathrm{aw}$. Thus, this is another cause of discrepancies in the wind power estimates. However, as indicated earlier, one cannot justify using one value of the power law over another in a national assessment.

General Electric extrapolated downward to $50 \mathrm{~m}$ from the $150 \mathrm{~m}$ rawinsonde estimates, stating: "it was felt a more consistent and reliable set of values would result as compared to extrapolation of wind energy up from the surface, where anemometer heights can vary quite radically---." General Electric initially used the 1/7 law (3/7 law for wind power) to extrapolate downward; however, some of the $50 \mathrm{~m}$ values were less than the values of surface wind power calculated from the Sandia data tape. To el iminate this problem, they established an empirical procedure where the ratio of $50 \mathrm{~m}$ to $150 \mathrm{~m}$ wind power used was as a function of the ratio of the $150 \mathrm{~m}$ wind power to surface wind power. Nevertheless, we find that the wind power estimates at $50 \mathrm{~m}$ based on this technique are 30-60\% lower over much of the Great Lakes, Midwest, and Great Plains than average estimates based on extrapolating up from $10 \mathrm{~m}$ (see Table 1). One explanation is that the twice a day rawinsonde measurements (morning and evening) do not properly account for the diurnal variation in wind speed. Surface winds are typically strongest in the afternoon. 
Techniques Applied to Estimate Mountain Top Wind Power

A11 three national assessments used statistics of Northern Hemisphere wind characteristics compiled by Crutcher $^{10}$ to estimate upper air wind power. These values were then applied to estimate typical mountain summit wind power. General Electric assumed that mountain summit wind power is approximately equal to the free air wind power at the summit height. Lockheed assumed that mountain summit wind speed is one-half of the free air wind speed $(1 / 8$ of the free air power), based on a study by $W a h 1 ;^{18}$ these values were taken to be at $10 \mathrm{~m}$ and extrapolated to $50 \mathrm{~m}$ using a 0.2 power law. Thus, Lockheed's mountain summit values for $50 \mathrm{~m}$ are approximately $1 / 3$ the free air values of wind power.

Since the relationship of mountain summit wind power to free air wind power at summit appears highly variable, there is no justification that one assumption gives more representative estimates than the other. Observed mean annual wind speeds of various mountain summits throughout the U.S. indicate that some summits or ridges may have greater wind power than the free air. Examples are Rattlesnake Mountain in south-central Washington with over $1000 \mathrm{~W} / \mathrm{m}^{2}$, Sandberg in the southern California coast range with over $500 \mathrm{w} / \mathrm{m}^{2}$, and Mt. Washington in New Hampshire with over $2000 \mathrm{~W} / \mathrm{m}^{2}$. However, some other mountain summits with wind data indicate considerably less wind power than expected; examples are provided in the Lockheed report.

Techniques Applied to Estimate Offshore Wind Power

General Electric used wind speed distributions from Marsden Squares and Navy Marine Areas, which are based on ship observations. Although there are uncertainties on the heights and accuracy of shipboard measurements, these data are valuable for identifying large scale patterns of wind power over offshore regions. Sandia's and Lockheed's estimates for coastal and offshore regions are primarily based on coastal stations, a few of which are located on offshore islands.

A comparison of the analyses for the coastal regions shows a few discrepancies, e.g., ship wind data indicates there is greater wind power along the central Gulf coast (Louisiana to northwest Florida) than along the Texas coast whereas coastal wind data indicates the reverse. However, in these areas with discrepancies, it is difficult to evaluate which estimates are most representative. If the average shipboard measurements are greater than $10 \mathrm{~m}$, then the values will be overestimated. 


\subsection{FINALIZED MAPS OF WIND POWER}

Each assessment used a different method of analysis in producing their finalized maps of wind power for the U.S. Sandia performed an objective smoothing of the surface estimates by geometric averaging of station values. General Electric did a subjective analysis based on rawinsonde and surface extrapolated estimates; and Lockheed plotted the values calculated for each station location, purposely avoiding isodynes. A brief description of the national analyses made by each assessment is given below.

Sandia

Maps were constructed showing annual and seasonal averages of available wind power at the surface and seasonal averages at the 850 and $700 \mathrm{mb}$ levels over the contiguous U.S. The surface maps reasonably identify regions of relatively high and low wind power. The national analyses of surface wind power potential were based on the unadjusted values computed from the Sandia tape of wind speed frequency distributions. A regional smoothing technique was used to average out the very large interstation variabilities in wind power, as differences were in some cases as much as a factor of 2 to 3 at nearby stations even over fairly homogeneous terrain. However, the regional smoothing technique used causes the analyses to be misrepresentative in some areas, e.g., along coastal regions, the onshore stations depress the offshore values.

\section{General Electric}

General Electric's final product was a combined analysis at $50 \mathrm{~m}$ for the U.S., based on a subjective analysis of the extrapolated surface, $150 \mathrm{~m}$ rawinsonde, offshore ship, and upper air estimates. Instead of wind power, their annual average estimates are in wind energy with units of megawatt-hours $/ \mathrm{m}^{2} / \mathrm{yr}$. One $\mathrm{MWh} / \mathrm{m}^{2} / \mathrm{yr}$ is equivalent to wind power of approximately $114 \mathrm{~W} / \mathrm{m}^{2}$. The estimates at $50 \mathrm{~m}$ are generally 30-60\% lower over most of the Great Plains, Midwest, and Great Lakes region than those by Sandia and Lockheed (see Table 1). This technique of extrapolating downward from $150 \mathrm{~m}$ rawinsonde data appears to significantly underestimate the wind power, as discussed earlier. The wind energy estimates along the central Gulf coast (Louisiana to northwest Florida), 
where over $4 \mathrm{MWh} / \mathrm{m}^{2}\left(450 \mathrm{~W} / \mathrm{m}^{2}\right)$ is indicated, may be too high. These estimates are based on ship data for just one Marsden square, and additional offshore data is needed to evaluate if these high estimates are realistic.

The geographical distributions of wind power over mountainous regions show isolated areas of relatively high and relatively low wind power. There are several regions (e.g., Washington and Oregon, and New Mexico and Arizona) where the relative geographical distributions of wind power over mountain regions do not appear consistent with the topography.

Lockheed

Lockheed purposely avoided isodyns and chose to construct maps showing the estimated values of wind power for each station. Maps of wind power were prepared for $10 \mathrm{~m}, 50 \mathrm{~m}$, and $100 \mathrm{~m}$ levels. In addition, a separate set of maps were constructed, which designated wind power class intervals by colored dots. Thus, individual stations and areas with relatively high wind power can readily be identified, in addition to the network density of stations within a region. An advantage of this type of analysis is that errors and misrepresentations resulting from drawing isodyns (subjectively or objectively) are eliminated. Interpretation of these values is primarily left up to the user. A disadvantage is that a user may interpret the individual values too literally and be misled. For example, the highest values may be assumed to be representative estimates for well exposed sites, when really some of these values may be considerably overestimated; likewise, areas with low values may be assumed to have low wind power when really many of these stations may be in sheltered locations. Thus, the user must be aware of the many uncertainties and errors which are inherent and may cause some of the individual estimates to be in error by a factor of 2 or more.

Over mountainous regions, extrapolated values of wind power over mountain peaks, based on the free air wind power at the height of the peak, are given for $1^{\circ}$ latitude by $1^{\circ}$ longitude squares. Two values are plotted for each $1^{\circ}$ square: a value for the highest peak and a value for a representative peak. Areas where these values appear questionable are where the valley estimates are greater than nearby mountain peak estimates. 


\subsection{SUMMARY OF THE TYPES OF ERRORS AND UNCERTAINTIES}

A summary of factors which lead to errors and/or uncertainties in the wind power estimates is listed below.

1. Incorrect specification of or neglect of anemometer heights. If the actual height is $20 \mathrm{~m}$, and the height is assumed or specified to be $10 \mathrm{~m}$, then the wind power may be overestimated from $35 \%$ (using $1 / 7$ power) to $52 \%$ (using 0.2 power). Conversely, the wind power may be underestimated if the actual height is less than the assumed height.

2. Number of wind speed classes. Wind power is overestimated by approximately $10-30 \%$ for stations with just 3-6 wind speed classes and by $5-15 \%$ for stations with 8-12 wind speed classes.

3. Atmospheric density variations with elevation. The use of standard sea level density overestimates the wind power by approximately $9 \%$ per $\mathrm{km}$ elevation.

4. Atmospheric density variations with air temperature. Errors from this source vary from region to region but are generally less than 5\% annually (see Section 4.1.).

5. Period of record. Typical year to year variation in mean wind speed are 10-20\%, which correspond to wind power variations of approximately $30-70 \%$. Thus, for stations for which the wind power estimates are based on less than 5 years. of data, the estimates may be in considerable error.

6. Vertical extrapolation techniques. Use of the 0.2 power to extrapolate upward from $10 \mathrm{~m}$ to $50 \mathrm{~m}$ gives $32 \%$ greater wind power than the $1 / 7$ power law.

7. Rawinsonde data at 150 meters. Extrapolating rawinsonde-based estimates at $150 \mathrm{~m}$ down to $50 \mathrm{~m}$, using a $1 / 7$ power law, generally underestimates the wind power at $50 \mathrm{~m}$ by approximately $30-60 \%$. 
8. Ship wind measurements. There are uncertainties regarding the accuracy and height of wind speed measurements made by ships.

9. Station location. Uncertainties may exist on how sheltered or exposed the location is with respect to surrounding terrain.

10. Instrument exposure. Uncertainties may exist regarding obstructions such as trees, buildings, etc.

11. Accuracy of the wind speed sensor. Errors of just $1 / 2 \mathrm{~m} / \mathrm{sec}(1 \mathrm{mph})$ in the mean wind speed cause large errors in wind power estimates, e.g., the average wind power for a $6 \mathrm{~m} / \mathrm{sec}$ wind speed is about $30 \%$ greater than that for a $5.5 \mathrm{~m} / \mathrm{sec}$ wind speed.

12. Method of observing and recording the wind speeds. The manner in which wind speeds are read and averaged may cause errors (e.g., instantaneous vs. 3 minute average vs. hourly average).

13. Analysis and interpolation of the wind power estimates. Different analys is methods may result in significantly different estimates and patterns, even though identical data sets are used. 


\section{THE REFINED ANALYSES OF NATIONAL WIND POWER}

\subsection{METHODS USED IN THE ANALYSES}

Refined analyses of wind power at $50 \mathrm{~m}$ above exposed areas over the contiguous U.S. (shown in figures 1 and 3 through 6 in the Summary) were developed through a synthesis and revision of existing national wind energy assessments and various other sources. This study did not attempt to take the various data sets employed and recompute the wind power. Due to the nature of the wind data used, it is felt that this effort, in itself, would have resulted in little, if any, improvement. Rather, the wind power estimates and analyses in each of the existing national assessments were evaluated subjectively with respect to the techniques applied and the representativeness of the data and the analyses. Over regions where large discrepancies existed, this included identifying the causes of these discrepancies. These criteria have been described throughout previous sections of this report and summarized in Section 5.3. Differences in the types of wind data used, the assumptions made, the techniques applied in the vertical extrapolation of winds, and the methods of analysis, primarily account for the discrepancies in the wind power estimates and geographical distributions.

In forming the refined analysis, information from the following sources was selectively and discriminately utilized:

1) surface wind power estimates from the national wind energy assessments,

2) wind power estimates from low-level rawinsonde wind speed distributions at $150 \mathrm{~m}$ (GE study),

3) offshore wind power estimates calculated for Marsden Square and Navy Marine Areas (GE study),

4) upper air wind power estimates and mountain summit wind power estimates,

5) Wind data summaries from various other sources, including Hewson, ${ }^{21}$ Justus, ${ }^{8}$ Wentink, ${ }^{22}$ and STAR program and climatological wind summaries from the National Climatic Center, 
6) national maps of topographic relief variation for evaluating the average local height variations of topography over areas of gently rolling and hilly terrain, and

7) national maps of the physical topographic features, for identifying regions of mountainous terrain.

The representativeness and reliability of the wind power estimates were stressed. Where possible, wind data sets or summaries from other sources (such as those listed above) and from more recent time periods were used for comparison with those in the national wind power assessments. For example, the mean annual speeds given in climatological summaries for recent time periods (for which anemometer heights are constant and instrument exposure are generally good) were compared with those in the Lockheed tabulations. 11 In regions of gently rolling and hilly terrain, some of the stations were examined for sheltering effects by local topography (i.e., to determine if the station is located in a relatively low area with respect to the elevation of the surrounding terrain).

Over nonmountainous terrain, the large-scale energy patterns based on $150 \mathrm{~m}$ level rawinsonde data are assumed to be generally representative of the relative energy patterns. However, the wind power estimates based on $150 \mathrm{~m}$ rawinsonde data are considered to be $30-60 \%$ too low in most cases (for reasons previously discussed) and were correspondingly adjusted.

Isolated high values for surface stations are not shown in the national wind power analyses. Many of these relatively high values are for stations with "limited" data (i.e., short time periods and 4 or fewer wind speed classes). As discussed earlier, there are several factors or combination of factors which can cause the wind power estimates for surface stations to be overestimated by as much as a factor of two.

The wind power estimates along coastal regions are based on (1) offshore wind power estimates calculated for Marsden Squares and Navy Marine Areas and (2) estimates for exposed coastal sites. Wind power estimates for the large Navy Marine Areas, which extend seaward $300 \mathrm{~km}$ or more, 
indicate considerably greater wind power (factor of 2) than that for Marsden Squares which are areas located within $100 \mathrm{~km}$ of the coast. The relative geographical distribution of wind power along coastal regions is assumed to be similar to the relative distribution for Navy Marine Areas and roughly one-half the magnitude, in most cases.

The offshore wind power values based on ship data and values for coastal stations are applied with discretion in determining the wind power estimates along coastal regions. Only annual average values for offshore areas were calculated in the assessment by General Electric. Thus, in the synthesis, seasonal values for offshore areas were adjusted in proportion to seasonal variations from the annual average at selected coastal stations.

The wind power estimates indicated off the Atlantic, Gulf, and Pacific coasts apply to exposed coastal sites (e.g., capes, points, and islands) and offshore areas. For definition purposes, this offshore zone may be assumed to extend from the shoreline $50 \mathrm{~km}$ seaward. (We suspect that the wind power may increase slightly from the shoreline seaward but have no conclusive information on this. We also suspect that the wind power at exposed coastal sites and at $1 \mathrm{~km}$ seaward is more typical of the power at 10-50 km seaward than at $1 \mathrm{~km}$ inland, primarily due to surface roughness effects.) Because of the sharp gradients of wind power along coastal areas, use of isodyns was avoided.

Since wind power over mountain summits appears highly variable and may be greater on relatively "isolated" ridges than on higher summits and ridges in the same region, it was felt that all regions with any significant mountains or ridges (e.g., $500 \mathrm{~m}$ or more higher than the surrounding terrain) should be analyzed with estimates for exposed mountain summits. Thus, regions with scattered or isolated mountain ridges such as the Great Salt Lake basin of northwest Utah are designated by typical estimates for the mountain summits rather than for the lower basin. (An exception was southern Wyoming, where exposed areas in the basin indicate high wind power 
comparable to that estimated for mountain summits.) These mountainous regions were defined using national relief maps, ${ }^{12}$ and are the shaded areas on the national wind power maps.

The wind power estimates given for mountain summits are lower limits expected for typical, well exposed sites. Sites where the wind speeds are enhanced by topographic effects may have more than double the amount indicated in the analyses. Examples are: Whiteface Mounta in in northern New York with approximately $1500 \mathrm{~W} / \mathrm{m}^{2}$, Rattlesnake Mountain in south central Washington with approximately $1000 \mathrm{~W} / \mathrm{m}^{2}$, and Sandberg in the southern California Coast Range with approximately $500 \mathrm{w} / \mathrm{m}^{2}$. Also, gaps and passes may have comparable wind power to nearby mountain summits.

\subsection{GEOGRAPHICAL DISTRIBUTIONS}

Annual and seasonal distributions of wind power at $50 \mathrm{~m}$ above exposed areas are shown in Figures 1 and 3 through 6 (in the Summary) and briefly described here. The intent of these analyses is primarily to describe the large scale distributions of wind power over the U.S. We have attempted to produce analyses which are simple, easy to interpret, and generally representative. Separate descriptions for Alaska and Hawaii are included toward the end of this section.

Annual Pattern in the Contiguous U.S.

Regions indicating high wind power $\left(400 \mathrm{~W} / \mathrm{m}^{2}\right.$ or greater), shown in Figure 1, are the southern and central Great Plains, offshore and well exposed coastal sites along the north Atlantic coast, north Pacific coast, and south Texas coast, the high plateau area of southern Wyoming, and areas just east of the Rockies in Montana. The analysis also indicates that most mountainous areas in the East and West should have exposed sites with considerable wind power. (Again, the estimates for mountain summits are lower 1 imits expected for well exposed sites.) As discussed earlier, many lower isolated ridges may also have considerable wind power and be more suitable for wind turbines than higher mountain ranges. 
Considerable wind power $\left(300 \mathrm{~W} / \mathrm{m}^{2}\right.$ or greater) is also indicated over the northern Great Plains. Some isolated areas in the northern Great Plains indicate over $400 \mathrm{~W} / \mathrm{m}^{2}$ (not shown in the analysis) but the density and representativeness of the data are not sufficient to identify the extent of these areas. More data are needed before additional detail in the analysis can be justified.

Over regions of complex terrain (hilly and mountainous terrain) and coastal areas, where local mesoscale effects can result in higher wind speeds, there is a possibility that a few sites may have as much as $100 \%$ greater wind power than the national analyses show.

Very limited data were available for offshore or exposed coastal sites along the Great Lakes. These data indicated that the wind power is substantially greater offshore and at exposed coastal sites than for inland areas. Thus, the offshore annual wind power over the Great Lakes is estimated to be over $300 \mathrm{~W} / \mathrm{m}^{2}$, which is approximately $100 \mathrm{~W} / \mathrm{m}^{2}$ greater than the average power for nearby inland sites. East shores of the lakes are expected to have greater wind power than the west shores, due to the prevailing westerly winds. Some wel1 exposed sites with 1 imited data indicate over $500 \mathrm{~W} / \mathrm{m}^{2} .2,16$ Seasonal Patterns of Wind Power in the Contiguous U.S.

The seasonal patterns of wind power are shown in Figures 3 through 6 for winter, spring, summer, and fal1, respectively, in the Summary. Figure 2 shows the seasons of maximum wind power. Over the eastern one-third of the nation, maximum wind power occurs during the winter and early spring, except for mountain summits where the maximum is in the winter. Spring maxima occur over the Great Plains, the North-Central states, the Texas coast, most nonmountainous regions in the West (e.g., the basins and broad valleys), and offshore areas of central and southern California. Winter maxima occur over a11 mountainous regions, except for some areas in New Mexico and Arizona where the spring and winter wind power are about equal. The Northwest coastal region, the high plateau of southern Wyoming, and a strip in Montana 
which lies just east of the Rocky Mountains, also have winter maxima. The only regions which have summer maxima are coastal and offshore areas of southern Oregon and northern California.

Wind Power in Alaska

A study of the wind power in Alaska and its possible application has been performed by Wentink. 22 Most offshore and exposed coastal regions of Alaska have high wind power potential. As in all coastal regions, the wind power typically decreases abruptly onshore, especially along more rugged coastlines. The highest wind power in the Alaska region appears to be along the Aleutian peninsula and island chain between $160^{\circ}-172^{\circ}$ longitude. Exposed coastal sites and offshore areas of the Aleutians indicate mean annual wind speeds of $7.0 \mathrm{~m} / \mathrm{sec}(16 \mathrm{mph})$ or greater and annual average wind powers exceeding $500 \mathrm{~W} / \mathrm{m}^{2}$.

Very good wind power $\left(400-500 \mathrm{~W} / \mathrm{m}^{2}\right)$ also exists along all other exposed coastal and offshore areas of Alaska. The wind power throughout interior Alaska and sheltered coastal regions (e.g., bays, inlets, and sounds in rugged terrain) appears quite low, except for mountains and isolated ridges. A few interior places show greater than $200 \mathrm{~W} / \mathrm{m}^{2}$; these are primarily canyons and valleys where the winds are enhanced by topography, such as Big Delta (about 80 miles southeast of Fairbanks).

Annual mean upper air wind speeds decrease from southwest to northeast Alaska, but the upper winds at $850 \mathrm{mb}$ and $700 \mathrm{mb}$ are sufficiently strong such that well exposed mountain sites throughout Alaska are estimated to have annual average wind powers of at least $300-400 \mathrm{~W} / \mathrm{m}^{2}$.

Wind Power in Hawa $i j$

Wind power along exposed coastal and offshore areas of the Hawaiian Islands is estimated to be $200-300 \mathrm{~W} / \mathrm{m}^{2}$, but some sites with limited data indicate over $400 \mathrm{w} / \mathrm{m}^{2}$. Inland areas show much lower wind power.

The variation of wind speed with height in the subtropics is strikingly different from that of the mid-latitudes. Above $850 \mathrm{mb}$ the wind speed 
generally decreases with height in the subtropics, so that lower mountain ridges in Hawaii are estimated to have greater wind power than the loftier volcanoes. ${ }^{3}$ Wind power studies for the islands of Hawaij, Oahu, and Maui have been made by the University of Hawaii.23,24,25 Numerical modeling studies of the wind flow characteristics over the island of 0ahu have been performed by Hardy. 26

\section{Diurnal Variation of Wind Power}

Diurnal wind power variations throughout the U.S. have been shown and described in previous national assessments. In the surface layer up to 100 or $200 \mathrm{~m}$, winds tend to be strongest in the afternoon and weakest after midnight for most areas. Over mountain summits, winds are generally stronger at night, based on the 1 imited data available. The survey by Lockheed indicates, however, that the diurnal behavior of wind speed may differ markedly from mountain to mountain. 


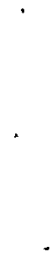

. 


\section{CONCLUSIONS}

A synthesis of the existing national wind energy assessments has been performed in an effort to develop an improved, consistent assessment of the available wind power and its geographical distribution over the United States and identify areas of needed research. Maps showing the distribution of annual and seasonal average wind power potential have been developed for the contiguous United States. Some primary results of the synthesized and refined national wind energy assessment are briefly sunmarized below.

- Wind power estimates for individual stations are subject to various errors and uncertainties in the data and techniques employed. Variations in anemometer heights, and site and instrument exposure can result in nearby wind power values which differ by a factor of 3 even over regions of mostly level terrain. Thus, surface-based wind power estimates should be used with caution.

- Rawinsonde data summarized for the $150 \mathrm{~m}$ level above the ground is useful for identifying the large scale energy patterns, but generally underestimates the wind power by $30-60 \%$.

- The estimates shown in this assessment are considered to be generally conservative. Over offshore areas and regions of complex topography, there may be we 11 exposed sites with as much as 100\% greater wind power than the amount indicated. (This is the total available power, not the extractable wind power.) Over all regions, there may be a few isolated sites or areas with considerably greater (up to $50 \%$ ) wind power than indicated.

- Over nonmountainous regions, the analysis indicates that annual wind power at $50 \mathrm{~m}$ above exposed is high $\left(\geq 400 \mathrm{~W} / \mathrm{m}^{2}\right)$ over the central and southern Great Plains, parts of Wyoming, Montana, and offshore and exposed coastal areas of the Northeast, Northwest, Alaska, Hawaii, and south Texas. Moderately high wind power $\left(\geq 300 \mathrm{~W} / \mathrm{m}^{2}\right)$ is indicated over the northern Great Plains and the Great Lakes. There is a possibility of isolated good sites throughout the rest of the country. 
- Al1 mountainous regions are expected to have some exposed mountains, ridges, or passes with high wind power potential, including regions where the upper air wind power is relatively low (such as the Southwest). The wind power is highly variable over mountainous regions and depends on the shape and orientation of a ridge, as well the height of a ridge.

- The seasons of maximum wind power are predominately winter over most mountainous regions, late winter and early spring over the eastern third of the nation, and spring over the central U.S. and Great Plains.

- Wind power is generally highest in the afternoon and weakest after midnight for most surface stations. Over mountain summits, winds are typically stronger at night. 


\section{RECOMMENDATIONS}

As a result of the synthesis of national assessments of wind energy performed in this study, the following recommendations are made.

- Surface values of wind power need to be evaluated using wind data from a recent 5-10 year period when the anemometer heights are constant over the period. Hourly, or three-hourly, digitized wind data available from the NCC could be utilized for this task. This would eliminate errors due to variations or uncertainties in the anemometer heights and due to the number of wind speed classes. Also, errors due to poor instrument exposure would be substantially reduced.

- The representativeness of wind power estimates for individual surface stations needs to be examined more thoroughly with regard to the exposure of the station (with respect to surrounding terrain and roughness) and to the exposure of the anemometer (with respect to nearby obstructions).

- The horizontal and vertical structure of wind power along coastal regions and for offshore areas needs to be examined in greater detail. Most coastal stations are located too far inland to be applicable, and there are uncertainties regarding the use of ship data. Techniques for estimating the alongshore and offshore variation of wind power, in the absence of representative data, need to be investigated.

- Summaries of tower wind data exist for numerous sites throughout the U.S. These summaries would be very useful in regional and national assessments of wind power. Wind data summaries from nuclear power plants have recently been compiled by Verholek. ${ }^{17}$ An effort should also be made to identify and aggregrate other tower wind data summaries, including those for coal-fired power plants.

- Using existing tower data, the variation of wind speed with height should be evaluated with respect to roughness height, local terrain influences, wind speed, seasonal and diurnal variations, and regional 
and climatological characteristics. Present relationships appear to be based on only a few separate sets of towers widely scattered throughout the country.

- Special wind data summaries compiled by universities, and private and federal agencies could provide additional information needed for improving the national and regional analyses of wind power, especially in regions where data is presently insufficient or questionable. Orgi11 27 has made a survey of field programs with mesoscale wind networks, for the Wind Energy Conversion Program. Similar surveys should be made to identify other data sources, through literature surveys, telephone contacts, etc.

- Extractable wind power needs to be evaluated and the geographical distribution of extractable wind power described for selected types of wind-powered generators, in a manner similar to that described by, Justus et al. ${ }^{4}$ but using additional data and techniques to refine and improve the analyses.

- An additional effort should be made to evaluate the reliability of wind power estimates derived from rawinsonde and pibal data by comparing with estimates computed from tower winds, provided the sites are close enough to permit such a comparison.

- With the available data sources used in this study, it is not likely that much additional detail can be analyzed into the national assessment of wind power. Using additional data sources, descriptive techniques, and models, regional assessments of wind power should be made to examine the potential wind power and its geographical distribution over various regions in greater detail. 


\section{REFERENCES}

1. J. W. Reed, Wind Power Climatology of the U.S. ERDA Contract \#AT(29-1) -789, SAND 74-0348, A1buquerque, NM, 1975.

2. Wind Energy Mission Analysis, Lockheed-California Co., Draft report, ERDA Contract AT(04-3)-1075, 1976.

3. Wind Energy Mission Analysis, General Electric Co. (Valley Forge), Draft report, ERDA Contract E(TT-1)-2578, 1976.

4. C. G. Justus, W. R. Hargraves and A. Yalcin, "Nationwide Assessment of Potential Output from Wind-Powered Generators." J. Appl. Meteor. 15(7):673-678, 1976.

5. W. K. Widger, "Estimating Wind Power Feasibility." Power Engineering, August 1976.

6. R. W. Baker and J.P. Hennessey, Jr., "Estimating Wind Power Potential." Power Engineering, March 1977.

7. M. J. Changery, Initial Wind Energy Data Assessment Study. NSF/NOAA, NSF-RA-N-75-020, Ashevi11e, NC, 1975.

8. C. G. Justus, Wind Energy Statistics for Large Arrays of Wind Turbines (New England and Central U.S. Regions). Final Report, NSF/RA- 76-0191, ERDA/NSF-00547/76/1, Georgia Institute of Technology, Atlanta, GA, 1976.

9. G. C. Holzworth, Mixing Heights, Wind Speeds, and Potential for Urban Air Pollution Throughout the Contiguous United States. EPA, Research Triangle Park, NC, 1972.

10. H. L. Crutcher, Upper Wind Statistics of the Northern Hemisphere. Vo1. 1, NAVAER 50-IC-535, Washington, DC, 1959.

11. U. A. Coty, A. Court, and J. W. Reed, United States Wind Speed and Wind Power Duration Tables, by Months (Cumulative Distributions). Scientific Report No. 1 under Contract AT(04-3)-1075, LockheedCalifornia Co., Burbank, CA., 1975.

12. The National Atlas of the United States of America, United States Department of the Interior, Geological Survey, Washington, DC, 1970.

13. C. G. Justus and A. Mikhail, "Height Variations of Wind Speed and Wind Distributions Statistics." Geophy. Res. Letters, 3, 261-264, 1976.

14. H. Newstein, An Automated Meteorological Instrumentation and Observing System on a $1000 \mathrm{ft}$ TV Tower. Drexel Univ., Final Report, ESSA/SDO Contract Cwb-11038, 1976. 
15. R. V. Cormier, An Annotated Listing - Tall Towers Instrumented for Wind Observations. Technical Report 73-0179, Air Force Cambridge Research Laboratory, L. G. Hanscom Field, Bedford, MA, 1973.

16. J. A. Wallace, Jr., An Annotated Bibliography of Meteorological Tower and Mast Studies. WB/BS-5, U.S. Department of Commerce, ESSA, Environmental Data Service, Washington, DC, 1967.

17. M. G. Verholek, Summary of Wind Data from Nuclear Power Plant Sites. BNWL-2220 WIND-4, Battelle, Pacific Northwest Laboratories, Richland, WA, 1977.

18. E. W. Wahl, Windspeed on Mountains. Final report, Contract No. AF19 $(628)-3873$, U.S. Air Force, Cambridge Research Laboratories, Bedford, MA, 1966.

19. J. Pristov, "Abweichungen des Windes auf den alpine Beabachtungsstationen im bezug auf die Strömung in der freien. Atmosphere. "Berichte des Deutschen Wittendienstes, Bd. 8, 5, 241-243, 1959.

20. R. N. Meroney, V.A. Sandborn, R.J.B. Bouwmeester, and M.A. Rider, Sites for Windpower Installations, Tunnel Simulation of the Influence of Two-Dimensional Ridges on Wind Speed and Turbulence, NSF/RANN GAER 75-00702, 1976.

21. E. W. Hewson, R. W. Baker, and R. Brownlow, Wind Power Potential in Selected Areas of Oregon. Report No. PUD 76-4, Oregon State University, Covallis, OR, 1976.

22. T. Wentink, Jr., Study of Alaskan Wind Power and Its Possible Applications. Final Report, Contract No. E(45-1)-2229; NSF-G-AER-7400239A01, Univ. of Alaska, Fairbanks, AK, 1976.

23. A. Danie1s, B. Palmer, T. Tarlpon, and T. Schroeder, A Survey of Wind on the Island of Maui for Potential Wind Power Generation. Part 1. Mobile Sampling Program, 7 August - 26 August 1976, Dept. of Meteorology, University of Hawai i, UHMET 76-6, 1976.

24. T. Schroeder, T. Tarlpon, and A. Daniels, A Survey of Wind on the Is land of Hawai i for Potential Wind Power Generation, Part 1. Mobile Sampling Program, 3 September - 12 September 1976, Dept. of Meteorology, University of Hawaii, UHMET 76-7, 1976.

25. C. Ramage, A. Daniels, T. Schroeder, and N. Thompson, Oahu Wind Power Survey, First Report. Dept. of Meteorology, University of Hawa i , UHMET 77-1, 1977. 
26. D. M. Hardy, Wind Studies in Complex Terrain, Lawrence Livermore Laboratory, Rept. UCRL-79430, 1977.

27. M. M. Orgi1l, Survey of Wind Measurement Field Programs, BNWL-2220 WIND-3, Battelle, Pacific Northwest Laboratories, Richland, WA, 1977. 

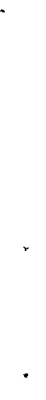
No. of

Copies

OFFSITE

1 ERDA Chicago Patent Group 9800 South Cass Avenue Argonne, Ill inois 60439

A. A. Churm

271 ERDA Technical Information Center
No. of

Copies

ONSITE

1. ERDA Richland Operations Office

G. L. Liffick

102 Battelle-Northwest

W. A. Cliff

R. L. Conley

R. L. Drake

D. L. Elliott (5)

C. E. Elderkin (80)

H. Harty

E. H. Phinney

J. V. Ramsdell

D. S. Renne

C. L. Simpson

R. L. Watts

L. L. Wende 11 Technical Information (5)

Technica1 Publications (2) (KK) 


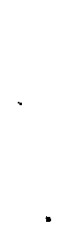

. 